\title{
A framework for ensemble modelling of climate change impacts on lakes worldwide: the ISIMIP Lake Sector
}

Malgorzata Golub ${ }^{1}$, Wim Thiery ${ }^{2}$, Rafael Marcé ${ }^{3,4}$, Don Pierson ${ }^{1}$, Inne Vanderkelen ${ }^{2}$, Daniel 5 Mercado $^{3}$, R. Iestyn Woolway ${ }^{5}$, Luke Grant ${ }^{2}$, Eleanor Jennings ${ }^{6}$, Jacob Schewe ${ }^{7}$, Fang Zhao ${ }^{8,7}$, Katja Frieler $^{7}$, Matthias Mengel ${ }^{7}$, Vasiliy Y. Bogomolov $9,10,11$, Damien Bouffard ${ }^{12}$, Raoul-Marie Couture $^{13,14}$, Andrey V. Debolskiy ${ }^{15,11}$, Bram Droppers ${ }^{16}$, Gideon Gal ${ }^{17}$, Mingyang Guo ${ }^{18}$, Annette B.G. Janssen ${ }^{16}$, Georgiy Kirillin ${ }^{19}$, Robert Ladwig ${ }^{20}$, Madeline Magee ${ }^{21}$, Tadhg Moore ${ }^{22,23}$, Marjorie Perroud ${ }^{24}$, Sebastiano Piccolroaz ${ }^{25,26}$, Love Raaman Vinnaa ${ }^{12}$, Martin Schmid ${ }^{12}$, Tom

10 Shatwell ${ }^{27,19}$, Victor M. Stepanenko ${ }^{15}$, Zeli Tan $^{28}$, Huaxia Yao ${ }^{29}$, Rita Adrian ${ }^{19,30}$, Mathew Allan $^{31,32}$, Orlane Anneville ${ }^{33}$, Lauri Arvola ${ }^{34}$, Karen Atkins ${ }^{35}$, Leon Boegman ${ }^{36}$, Cayelan Carey ${ }^{23}$, Kyle Christianson ${ }^{37}$, Elvira de Eyto ${ }^{38}$, Curtis DeGasperi ${ }^{39}$, Maria Grechushnikova ${ }^{15}$, Josef Hejzlar ${ }^{40}$, Klaus Joehnk ${ }^{41}$, Ian D. Jones ${ }^{42}$, Alo Laas ${ }^{43}$, Eleanor B. Mackay ${ }^{44}$, Ivan Mammarella ${ }^{45}$, Hampus Markensten $^{46}$, Chris McBride ${ }^{32}$, Deniz Özkundakci ${ }^{32}$, Miguel Potes ${ }^{47,48}$, Karsten Rinke ${ }^{27}$, Dale

15 Robertson $^{49}$, James Rusak ${ }^{29}$, Rui Salgado ${ }^{50}$, Leon van den Linden ${ }^{51}$, Piet Verburg ${ }^{52}$, Danielle Wain $^{53}$, Nicole K. Ward ${ }^{23}$, Sabine Wollrab ${ }^{19}$, Galina Zdorovennova ${ }^{54}$

${ }^{1}$ Uppsala University, Department of Ecology and Genetics, Uppsala, Sweden

2 Vrije Universiteit Brussel, Department of Hydrology and Hydraulic Engineering, Brussels,

Belgium

${ }^{3}$ Catalan Institute for Water Research (ICRA), Girona, Spain

${ }^{4}$ University of Girona, Girona, Spain

${ }^{5}$ University of Reading, Department of Meteorology, Reading, UK

${ }^{6}$ Dundalk Institute of Technology, Centre for Freshwater and Environmental Studies, Dundalk,

Ireland

7 Potsdam Institute for Climate Impact Research (PIK), Member of the Leibniz Association, Potsdam, Germany

8 Key Laboratory of Geographic Information Science (Ministry of Education), School of Geographic Sciences, East China Normal University, Shanghai, China.

$30{ }^{9}$ Institute of Monitoring of Climatic and Ecological Systems of the Siberian Branch of the Russian Academy of Sciences, Tomsk, Russia

${ }^{10}$ Tomsk State University, Tomsk, Russia

${ }^{11}$ Obukhov Institute for Atmospheric Physics, Russian Academy of Science, Moscow, Russia

${ }^{12}$ Eawag: Swiss Federal Institute of Aquatic Science and Technology, Surface Waters - Research

35 and Management

${ }^{13}$ Université Laval, Department of chemistry, Quebec, Canada

${ }^{14}$ Center for Northern Study, Quebec, Canada 
${ }^{15}$ Lomonosov Moscow State University, Moscow, Russia

${ }^{16}$ Wageningen University \& Research, Water Systems and Global Change Group, Wageningen, the Netherlands

${ }^{17}$ Kinneret Limnological Laboratory, Israel Oceanographic \& Limnological Research, Migdal, 5 Israel

${ }^{18}$ Purdue University, Department of Earth, Atmospheric and Planetary Sciences, West Lafayette, IN, USA

${ }^{19}$ Leibniz Institute of Freshwater Ecology and Inland Fisheries, Berlin, Germany

${ }^{20}$ University of Wisconsin-Madison, Center for Limnology, Madison, WI, USA

${ }^{21}$ Wisconsin Department of Natural Resources, Madison, WI, USA

${ }^{22}$ Dundalk Institute of Technology, Department of Applied Sciences, Dundalk, Ireland

${ }^{23}$ Virginia Tech, Department of Biological Sciences \& Forest Resources \& Environmental Conservation, Blacksburg, Virginia, USA

${ }^{24}$ University of Geneva, Institute for Environmental Sciences, Geneva, Switzerland

${ }^{25}$ University of Trento, Department of Civil, Environmental and Mechanical Engineering, Trento, Italy

${ }^{26}$ École Polytechnique Fédérale de Laussane, Physics of Aquatic Systems Laboratory (APHYS)Margaretha Kamprad Chair, Lausanne, Switzerland

${ }^{27}$ Helmholtz Centre for Environmental Research - UFZ, Department Lake Research, Magdeburg,

20 Germany

${ }^{28}$ Pacific Northwest National Laboratory, Richland, WA, USA

${ }^{29}$ Dorset Environmental Science Centre, Ontario Ministry of Environment, Conservation and Parks, Dorset, ON, Canada

${ }^{30}$ Freie Universität Berlin; Berlin, Germany

${ }^{31}$ Waikato Regional Council, Hamilton, New Zealand

${ }^{32}$ University of Waikato, Environmental Research Institute, Hamilton, New Zealand

${ }^{33}$ INRAE, Université Savoie Mont-Blanc, UMR CARRTEL, France

${ }^{34}$ Lammi Biological Station, University of Helsinki, Finland

${ }^{35}$ Tahoe Environmental Research Center, University of California, Davis, Davis, USA

${ }^{36}$ Queen's University, Department of Civil Engineering, Kingston, ON, Canada

${ }^{37}$ University of Colorado, Institute of Arctic and Alpine Research, Boulder, CO, USA

${ }^{38}$ Marine Institute, Furnace, Newport, Co. Mayo, F28X252, Ireland.

${ }^{39}$ King County Department of Natural Resources and Parks, Seattle, WA, USA

${ }^{40}$ Biology Centre of the Czech Academy of Sciences, Institute of Hydrobiology, České Budějovice,

35 Czech Republic

${ }^{41}$ CSIRO Land and Water, Canberra, Australia

${ }^{42}$ University of Stirling, Biological and Environmental Sciences, Stirling, UK

${ }^{43}$ Estonian University of Life Sciences, Chair of Hydrobiology and Fishery, Institute of Agricultural and Environmental Sciences, Tartu, Estonia 
${ }^{44}$ UK Centre for Ecology \& Hydrology, Lake Ecosystems Group, Bailrigg, Lancaster, LA1 4AP, United Kingdom

${ }^{45}$ University of Helsinki, Institute for Atmospheric and Earth System Research / Physics, Helsinki, Finland

${ }^{46}$ Swedish University of Agricultural Sciences, Department of Aquatic Sciences and Assessment, Sweden

${ }^{47}$ Universidade de Évora, Instituto de Ciências da Terra - ICT (Polo de Évora), Instituto de Investigação e Formação Avançada (IIFA), Évora, Portugal

${ }^{48}$ Universidade de Évora, Earth Remote Sensing Laboratory (EaRSLab), Instituto de Investigação

10 e Formação Avançada (IIFA), Évora, Portugal

${ }^{49}$ U.S. Geological Survey, Upper Midwest Water Science Center, Madison, WI, USA

${ }^{50}$ Universidade de Évora, Instituto de Ciências da Terra, Departamento de Física, Escola de Ciências e Tecnologia, Évora, Portugal

${ }^{51}$ South Australian Water Corporation, Adelaide, Australia

$15{ }^{52}$ National Institute of Water and Atmospheric Research, Hamilton, New Zealand

537 Lakes Alliance, Belgrade Lakes, Maine, USA 04901

${ }^{54}$ Northern water problems Institute Karelian Research Centre of RAS, Petrozavodsk, Russia

Correspondence to: Wim Thiery (wim.thiery@vub.be)

20 Abstract

Empirical evidence demonstrates that lakes and reservoirs are warming across the globe. Consequently, there is an increased need to project future changes in lake thermal structure and resulting changes in lake biogeochemistry in order to plan for the likely impacts. Previous studies of the impacts of climate change on lakes have often relied on a single model forced with limited scenario-driven projections of future climate for a relatively small number of lakes. As a result, our understanding of the effects of climate change on lakes is fragmentary, based on scattered studies using different data sources and modelling protocols, and mainly focused on individual lakes or lake regions. This has precluded identification of the main impacts of climate change on lakes at global and regional scales and has likely contributed to the lack of lake water quality considerations in policy-relevant documents, such as the Assessment Reports of the Intergovernmental Panel on Climate Change (IPCC). Here, we describe a simulation protocol developed by the Lake Sector of 
the Inter-Sectoral Impact Model Intercomparison Project (ISIMIP) for simulating climate change impacts on lakes using an ensemble of lake models and climate change scenarios. The protocol prescribes lake simulations driven by climate forcing from gridded observations and different Earth system models under various Representative Greenhouse Gas Concentration Pathways, all consistently bias-corrected on a $0.5^{\circ}$ x $0.5^{\circ}$ global grid. In ISIMIP phase 2, 11 lake models were forced with these data to project the thermal structure of 62 well-studied lakes where data were available for calibration under historical conditions, and for nearly 17,500 lakes using uncalibrated models and forcing data from the global grid where lakes are present. In ISIMIP phase 3, this approach was expanded to consider more lakes, more models, and more processes. The ISIMIP Lake Sector is the largest international effort to project future water temperature, thermal structure, and ice phenology of lakes at local and global scales and paves the way for future simulations of the impacts of climate change on water quality and biogeochemistry in lakes.

\section{Introduction}

Even though there are over 117 million lakes on Earth, and they cover only tiny fraction $(\sim 3 \%)$ of the Earth's continental surface (Verpoorter et al., 2014), lakes are among the most anthropogenically altered ecosystems on Earth (Carpenter et al., 2011, Jenny et al. 2020), and while many impacts on lakes are local, climate change is a global driver interacting with all other pressures influencing lakes, regardless of their scale. It is necessary to disentangle the global impacts of climate change from other anthropogenic pressures to strengthen mitigation and adaptation measures. However, global estimates of historical and future lake responses to climate change have largely been carried out as site-specific studies with different goals, data and modelling protocols, which complicates the generalization of simulated impacts at regional and global scales (Settele et al., 2014; Masson-Delmotte et al., 2018). 
Historical records show that lakes are already responding to climatic change by warming (O'Reilly et al. 2015, Pilla et al., 2020, Jane et al., 2021, Gal et al., 2020), experiencing declining ice cover (Sharma et al. 2019; Weyhenmeyer et al. 2011), shifting thermal habitats (Kraemer et al., 2021), changing mixing regimes (Woolway and Merchant, 2019 ; Kraemer et al. 2015), and decreasing oxygen levels (Jane et al., 2021). However, long-term monitoring data remain limited to a relatively small number of well-studied lakes, while time series from automated high sampling frequency monitoring buoys are still generally short (Marcé et al. 2016). The existing empirical evidence needs to be combined with lake models to understand how lakes have responded to historical changes (Moras et al., 2019) and how they could behave under future climatic change. Numerous numerical models have been used to assess climate change impacts on lake ecosystems (Ayala et al. 2020 2019; Piccolroaz, Woolway, and Merchant 2020; Hansen et al. 2017; Schwefel et al. 2016); however, the climate change impacts synthesized in the recent IPCC reports remain limited to a small number of lakes, regions or specific impact models or climate change scenarios (Kramer et al. 2015, Masson-Delmotte et al., 2018). Multi-model ensemble simulations are increasingly used to obtain more robust assessments of freshwater ecosystem responses to climate change, but so far, only a few lakes have been assessed following a multi-model approach (Perroud et al. 2009; Trolle et al. 2014; Stepanenko et al. 2010; 2013; 2014; Thiery et al. 2014; Gal et al. 2020; Guseva et al., 2020). To date, no multi-model ensembles have been used over a broad range of lakes to make either hindcast or future climate simulations, which would allow evaluating the variability in model output related to different model formulations or parametrizations.

The ISIMIP framework (www.isimip.org) provides a set of climate and socioeconomic forcing data to make consistent historical hindcast and future climate impact projections and evaluate impacts in response to policy-relevant climate change scenarios. ISIMIP is organized in different sectors ranging from hydrology to human health, all of which make use of common and openly provided input data. As part of ISIMIP, we initiated the Lake Sector and developed a lake model simulation protocol to assess climate change impacts on lakes and to provide robust scientific evidence of historical and potential future lake ecosystem changes. To this end, we used two complementary 
strategies: (i) a local strategy to simulate 62 well-studied lakes where sufficient data were available for lake specific model parameterization and calibration; and (ii) a global strategy that applied lake models to a generic lake for each land grid cell of the 17,500 ISIMIP global grid with information on lake surface area and depth. The simulation setup described by the protocol enables projecting and attributing impacts of climate change on lake water temperature. The protocol allows incorporating uncertainties derived from the differences in global climate models (GCMs), the differences in lake impact model structure, and lake geographical and ecosystem characteristics. The standardized output produced by the hydrodynamic lake models included vertical profiles of water temperature and metrics describing thermal and ice conditions at daily to annual time scales.

10 The multi-model ensemble provided a systematic overview of plausible future responses of lake ecosystems to a warming climate at an unprecedented geographical coverage. The forcing data from the GCM ensemble further enabled us to quantify lake responses to changes in meteorological variables other than air temperature, e.g., from wind velocity or cloud cover (Woolway et al., 2019, Mi et al., 2018), including their potential interactions with increases in air temperature. Completed and ongoing thermal regime simulations will provide the foundation for the modelling of water quality, greenhouse gas emissions, algal blooms (Janssen et al., 2019), and water level fluctuations to be addressed in future ISIMIP rounds.

Here, we describe the protocol for the global- and local-scale intercomparison of lake models in phase 2 (ISIMIP2) as well as the extensions implemented for the ongoing phase 3 round (ISIMIP3). First, we provide an overview of the climate data and climate change scenarios available through ISIMIP that were used as forcing data for lake impact models. Next, we explain the rationale behind the ISIMIP Lake Sector, give an overview of the impact simulations, and briefly describe the lake models used at local and global spatial domains. Finally, we highlight some examples of the first lake impact model simulations from the ISIMIP2 simulation phase and illustrate how the simulations allowed us to quantify sources of uncertainty in future projections.

The Lake Sector simulations are the first consistent ensemble projections of climate change impact on lakes, which will provide guidance to researchers, policymakers, and water managers as well as 
enable comparison of impacts with other sectors participating in ISIMIP. Given the importance of lake thermal structure in regulating lake processes, ISIMIP2 simulation results from the Lake Sector provide a fundamental contribution to lake specific policy recommendations in reports from organizations like the IPCC, the Intergovernmental Science-Policy Platform on Biodiversity and

5 Ecosystem Services (IPBES), and the UN Environment Programme World Water Quality Alliance (UNEP-WWQA). Furthermore, the work described here paves the way for lake water quality simulations playing a fundamental role in international policy.

\section{The Lake Sector in the ISIMIP framework}

The ISIMIP2 simulation framework was divided into two simulations rounds: ISIMIP2a and ISIMIP2b. ISIMIP2a focused on historical simulations, which were forced with gridded climate reanalysis products based on observed meteorological data. The ISIMIP2b simulation round focussed on quantifying the impacts of GCM-derived historical and CMIP5 (Coupled Model Intercomparison Project Phase 5) projected climate change relative to a pre-industrial control (Frieler et al., 2017). For the Lake Sector, ISIMIP2a simulations centred around the calibration of

15 lake models at the local scale that were used for the future climate ensemble simulations in ISIMIP2b. These simulations also evaluated the lake models' ability to simulate observed climate variability and extremes at both local and global scales. The subsequent simulation phase, ISIMIP3a-b, will build on the latest gridded observations and CMIP6 global climate model simulations to provide meteorological forcing and improve the representation of non-climatic input data, such as land use and a dynamic global lake mask, which will be used to produce a new generation of lake model simulations.

The inception of the Lake Sector and the gathering of the first collection of models, modelling teams, and lake data providers greatly benefited from contributions from two global collaborative projects. First, the Lake Model Intercomparison Project (LakeMIP, https://www.unige.ch/climate/lakemip) started in 2008 (Stepanenko et al., 2010) with the objective 
of comparing the thermodynamic regime of lakes (including lake-atmosphere interactions) in a wide range of climatic conditions and mixing regimes as simulated by several one-dimensional lake models (Perroud et al. 2009, Stepanenko et al., 2013, 2014; Thiery et al., 2014; Guseva et al., 2020). Second, the Global Lake Ecological Observatory Network (GLEON, https://gleon.org, Weathers et al., 2013) started in 2005, with the aim of conducting innovative science by sharing and interpreting lake data to understand, predict, and communicate the role and responses of lakes in a changing global environment.

\section{Experimental setup}

10 The simulations followed the network-wide simulation protocols for ISIMIP 2a-b (Frieler et al., 2017; Schewe et al., 2019) and ISIMIP3a-b (see https://www.isimip.org/protocol/ for an overview). Here, we describe the rationale and specifics of simulations in the Lake Sector. Lake model simulations were conducted in two spatial domains: local and global (Fig. 1). Climate change impacts were simulated for existing lakes in the local domain and "representative" lakes in the global domain. These two complementary spatial domains balanced the need for site-specific information and the need for a global assessment of climate change impacts on lakes. All temperature simulations were conducted under the assumption that the water level of the lakes remained constant and, therefore, the lakes were decoupled from their watersheds. This assumption allowed us to make evaluations of lake dynamics based on meteorological forcing data only and was judged acceptable for this first phase of lake sector simulations. It is planned that subsequent simulations, especially those that will evaluate changes in lake biogeochemistry, will abandon this simplification and contribute to cross-sectorial collaborations. 


\subsection{Case-study lakes in the local domain}

Lakes in the local domain had sufficient information to allow the lake models to be parameterized using individual lake bathymetry and to be calibrated against measured water temperature profiles. Consequently, the local lake data set was a unique resource for testing and evaluating lake model

5 performance.

For ISIMIP2, bathymetric data and historical data on water temperature from 52 lakes and 10 reservoirs (Fig. 1a, Table S1) were shared among participating modelling teams. Since reservoirs were treated like regular lakes in the simulations, all waterbodies are hereafter called "lakes" (see section 4.3). The geographical distribution of the lakes encompassed a gradient of five major climatic groups in the Köppen-Geiger climate classification, including tropical, arid, temperate, boreal, and polar. Temperate and boreal lakes located in the Northern Hemisphere comprised $87 \%$ of all case-study lakes. The surface area of lakes ranged from 0.011 to 2,700 $\mathrm{km}^{2}$, with an average and median area of 121.1 and $8.9 \mathrm{~km}^{2}$, respectively. Two-thirds of lakes covered surface areas between 1 and $100 \mathrm{~km}^{2}$. The average and median mean depth of lakes were 26.3 and $10.8 \mathrm{~m}$ (range:

15 1.7-304.8 m), where $90 \%$ of the lakes were deeper than $3 \mathrm{~m}$. The Secchi depths reported for 49 of the lakes were $4.9 \mathrm{~m}$ (average) and $3.5 \mathrm{~m}$ (median) and ranged from $0.5 \mathrm{~m}$ to $32 \mathrm{~m}$, which indicated a wide range of lake trophic status.

In ISIMIP3, the same approach is followed, but the number of lakes is expanded. This is achieved through a data call to the research community, and by capitalizing on existing data harmonization efforts (e.g., Pilla et al., 2021).

\subsection{Representative lakes in the global domain}

Lakes in the global domain considered a generic lake in each of the 17,500 grid cells that contain lakes within the ISIMIP2 $0.5^{\circ}$ by $0.5^{\circ}$ global grid. Uncalibrated lake model simulations were performed on each of these generic lakes. 
To assign the bathymetry to these generic lakes in the global domain of ISIMIP2, the average lake depth and lake surface area were calculated based on a rasterized version of the Global Lake and Wetland Database (Lehner and Doll, 2004). Specifically, for each grid cell, average lake depth and lake surface area values were calculated from all lake data contained within that cell. Lake bathymetry for each cell was assumed to be cylindrical. The 17,500 generic lakes are assumed to be representative of all lakes within each $0.5^{\circ}$ grid cell (Subin et al., 2012). This approach based on mean lake characteristics in the grid cell could not account for the spatial distribution, variability, and non-uniform distribution in the depth and area of lakes in a grid cell. However, similar representations of lakes were used in Earth System and Numerical Weather Prediction Models

10 (Subin et al., 2012, Balsamo et al., 2012, Thiery et al., 2015, 2016, Vanderkelen et al., 2021). The grid cell lake representation was a necessary trade-off between computational feasibility and global representativeness. In the case of the global simulation model CLM4.5 (see section 3.3.2 below), all representative lakes had a constant $50 \mathrm{~m}$ depth. The global-scale lake coverage made it possible to represent lakes in all major climatic classes and their subclasses, which was not possible in the local lake domain. The global average, median and maximum surface area were $146 \mathrm{~km}^{2}, 67 \mathrm{~km}^{2}$, and $3091 \mathrm{~km}^{2}$, respectively, while lakes with an area between 10 and $100 \mathrm{~km}^{2}$ comprised $60 \%$ of all lakes. The mean depth of the representative lakes ranged from 1.9 to $1000 \mathrm{~m}$, with average and median values of $12.9 \mathrm{~m}$ and $10 \mathrm{~m}$, respectively (see Fig 3a).

In the ISIMIP3 simulation round, an updated lake mask including reservoirs was used (Fig. 3b and c). This new lake mask was based on the HydroLAKES (Messager et al., 2016) and Global Reservoir and Dam databases v1.3 (GRanD; Lehner et al., 2011), containing 1.42 million individual lake polygons and 7320 reservoir polygons. These polygons were converted to the $0.5^{\circ}$ by $0.5^{\circ}$ ISIMIP grid, giving lake area fraction per grid cell (Vanderkelen et al., 2020). In addition, the new datasets accounted for the increase in lake area due to reservoir construction, based on GRanD. The lake depth dataset providing average lake depth per grid cell, was updated to the Global Lake Database v3 (Choulga et al., 2019), for which the original data was remapped from 30"' to match 
the ISIMIP grid. Lake depth was, however, static and hence did not account for reservoir operations. The lake input was published with the following DOIs: https://doi.org/10.48364/isimip.263794 (for ISIMIP3a) and https://doi.org/10.48364/isimip.383948 (for ISIMIP3b).

\subsection{Lake models participating in ISIMIP}

5 Currently, 10 different lake impact models participate in the ISIMIP Lake Sector, where for some models two different versions were applied (Table 1). There are 8 lake models providing calibrated simulations in the local domain: air2water4par, air2water6par, ALBM, FLake-IGB, GLM, GOTM5.1, MyLake, and Simstrat. The global ensemble consists of 6 lake impact models: ALBM, CLM, GOTM5.3, LAKE, Simstrat-UoG and VIC-LAKE. In the sections below, these models are briefly described. For the models that contribute to both the local and global spatial domains, the global impact model section (3.3.2) only describes the differences compared to the local version of the model used.

\subsubsection{Lake models for local simulations}

air2water is a hybrid of a physically based and statistical model which simulates lake surface water temperature and epilimnion thickness solely based on air temperature as external forcing (Piccolroaz et al., 2013). The model estimates lake temperature in a single layer characterized by a time-varying thickness according to an empirical relationship accounting for the effect of thermal stratification. Within ISIMIP, two different versions of this model provided simulations for local lakes: air2water4par and air2water6par; these two setups of the model differ in the number of parameters affecting the lake thermal dynamics (Piccolroaz et al., 2016). The air2water model has been applied in lakes of varying climatic and morphometric conditions worldwide (Toffolon et al., 2014; Prats and Danis, 2019; Piccolroaz et al., 2020).

The Arctic Lake Biogeochemistry Model (ALBM) is a one-dimensional process-based coupled 
temperature dynamics, ice phenology, phytoplankton and dissolved nitrogen, oxygen, carbon dioxide and methane. ALBM was originally developed for Arctic lakes (Tan et al., 2015, 2017) but has been used for other lakes across the globe (Guo et al., 2020, 2021; Tan et al., 2018). The thermal regimes of lakes is simulated in ALBM using 1D thermal diffusion equations in both water and sediment columns with atmospheric boundary conditions driven by sensible heat, latent heat, thermal radiation, and solar radiation. ALBM simulates 51 irregular lake layers. Snow and ice dynamics are solved using one snow layer, one white/gray ice layer that is formed when too much snow is accumulated, and multiple black ice layers (Tan et al., 2018).

FLake-IGB (v2.0) is a one-dimensional model specifically designed to represent the effects of inland waters in climate models and numerical weather prediction systems (Mironov et al., 2008). FLake uses a two-layer parametric representation of the lake water column. The upper layer is vertically homogeneous, representing the surface layer produced by wind and convective mixing at the lake surface. The lower layer represents the thermally stratified part of the water column. Two additional layers simulate the ice cover and the lake sediment. The vertical temperature distribution in each layer is modelled by a parameterized function of vertical coordinate, derived from a selfsimilar representation of the temperature profile. For calculation of surface heat fluxes, the model input includes standard meteorological variables describing the air-lake interaction: air temperature and humidity, wind force, and long-wave atmospheric radiation (or cloud amount for its calculation). The short-wave solar radiation enters the model equations as the volumetric source term distributed across the water column. The FLake-IGB version used here uses longwave radiation as a direct input, instead of calculating it from cloud cover.

The General Lake Model (GLM, v3.0) is a one-dimensional hydrodynamic lake model, which simulates temperature stratification in lakes (Hipsey et al., 2019). It uses a flexible Lagrangian grid, and an energy budget approach to simulate mixing. The vertical layer structure can change in number and thickness throughout a simulation, following changes in stratification and lake volume. In this study, we based the initial number of layers on the initial water depth. In addition, GLM includes modules for surface heat exchange and ice/snow dynamics, vertical mixing, and water 
balance dynamics. GLM can be coupled to the Aquatic Ecodynamics Modelling Library (AED) to simulate water quality dynamics and ecosystem interactions.

The General Ocean Turbulence Model (GOTM v5.3) is a one-dimensional model that simulates the most important hydrodynamic and thermodynamic processes related to vertical mixing (Umlauf et al. 2005). GOTM was developed by Burchard et al. (1999) for modelling turbulence in the oceans, but it has been recently adapted for use in lakes (Sachse et al., 2014). Typically, GOTM is used as a stand-alone model for investigating the dynamics of boundary layers in natural waters, but it can also be coupled to a biogeochemical model using the Framework for Aquatic Biogeochemical Models (FABM; Bruggeman and Bolding, 2014)

MyLake (v1.12) is a one-dimensional process-based model used to simulate physical, chemical and biological dynamics in lakes (Saloranta \& Andersen 2007). The model simulates thermal stratification, lake ice and snow cover and phosphorus-phytoplankton dynamics. It also contains a simple sediment box-model. Optionally, the lake layers can be defined according to water volume. Simstrat (v2.1.2) is a one-dimensional hydrodynamic model, which specifically includes vertical mixing induced by internal seiches that is not included in most other models (Goudsmit et al., 2002). The model uses layers of fixed depth and supports multiple options for external forcing, comprising several meteorological variables or surface energy fluxes. The model simulates thermal stratification, ice and snow formation (Gaudard et al., 2019). Simstrat has been applied in lakes of varying climatic and morphometric conditions (e.g., Thiery et al., 2014; Kobler and Schmid, 2019; Mesman et al., 2020) and is operationally applied to a suite of Swiss lakes (Gaudard et al., 2019).

\subsubsection{Lake models for global simulations}

The Community Land Model (CLM). Version 4.5 of CLM (Lawrence et al., 2011, Oleson et al., 2013) is a land surface model that includes simulations with the Lake, Ice, Snow and Sediment

25 Simulator (LISSS; Subin et al., 2012). The CLM4.5 model has been used by multiple ISIMIP sectors with one consistent setup. CLM4.5 simulations and their outputs have been analysed to 
assess climate change impacts across a range of indicators within ISIMIP (e.g., Schleussner et al., 2018, Lange et al., 2020, Ito et al., 2020, Gudmundsson et al., 2021, Pokhrel et al., 2021, Gaedeke et al., 2021, Reinecke et al., 2021; Thiery et al., 2021).

LAKE is an extended one-dimensional model, that simulates thermodynamic, hydrodynamic and

biogeochemical processes in the water column and the bottom sediments of the lakes (Stepanenko et al., 2016). The model simulates vertical heat transfer considering the penetration of short-wave radiation (Heiskanen et al., 2015), ice, snow and bottom sediments. The model explicitly accounts for the exchange of momentum, heat, and dissolved gases between water and the inclined bottom. VIC-LAKE is a 1D lake model derived from the Variable Infiltration Capacity (VIC) Macroscale

10 Hydrologic Model (Bowling et al., 2010) and optimized for simulations at a sub-daily timescale. The model is based on a lake energy balance by Hostetler and Bartlein (1990), Hostetler et al (1991) and Patterson and Hamblin (1988). Turbulent mixing is solved with Henderson-Sellers thermal diffusion models using parametrized eddy diffusivity (Henderson-Sellers, 1985). The model also contains an ice module, which dynamically simulates lake ice and ice snow cover.

15 Simstrat-UoG v1 is based on Simstrat v1.4, which is described above, but additionally includes an ice routine and varying albedo.

\subsection{Input data}

\subsubsection{ISIMIP2a}

The Lake Sector simulation protocol for ISIMIP2a in its current form was completed in early 2020 and focused on the calibration of models in the local lake domain using the gridded ISIMIP2a data set. Eight lake models participated in this local lake simulation round. The calibration of the global lake models was unfeasible because of lack of a global-scale data set of measured lake water temperatures. 
Meteorological data from 1979 to 2016 at $0.5^{\circ}$ global grid (EWEMBI, "EartH2Observe, WFDEI and ERA-Interim data Merged and Bias-corrected for ISIMIP”, Lange, 2019a) were used to calibrate the local lake models. Meteorological data from the grid cell from each lake's geographical location (Fig. 1 and Table S1) were used for the model calibration. Since the majority of lakes lacked nearby weather stations, the uniform EWEMBI data allowed us to include a broader diversity of lakes and avoid cumbersome data harmonization. Since the EWEMBI data set was also used to help bias-correct the future climate scenarios used in the ISIMIP2b simulation round (Frieler et al., 2017, Lange, 2019b), the performance of calibrated lake models can be indicative of their ability to simulate past and future climate change when forced by the ISIMIP bias-corrected data. In addition to the calibration runs that were limited to periods when observed water temperature data were available, the local sector modellers were encouraged to drive their lake models with the complete EWEMBI data record between 1979-2016. This was aimed at evaluating the lake models' abilities to reproduce effects of observed meteorologic variability and extreme events on thermal simulations. These simulations could also be used for benchmarking simulations forced with modelled future climate conditions from GCMs. In addition to the EWEMBI data set, five other reanalysis data sets were provided in ISIMIP2a for modelers to use as inputs according to their capacities, with the goal of exploring the effect of input data choice on simulation outcomes. All datasets are described and referenced in the simulation protocol document (https://www.isimip.org/protocol/2a/).

20 Data providers supplied historical measured water temperature profiles for 62 lakes (Fig. 1a, Table S1). Lake data had to meet two criteria to be included in the local lake data set: (1) data needed to overlap with the EWEMBI time span and temperature profiles needed to encompass at least two consecutive years in the case of (sub)-daily sampling frequency, or at least five consecutive years in the case of (sub)-monthly sampling frequency. These criteria enabled intra- and inter-annual variability to be captured in water and meteorologic conditions in the model calibration procedure. A few lakes from under-represented geographical locations (e.g., tropics) were included despite shorter water temperature records. 
Water temperature data were harmonized to a uniform data format and visually quality-controlled to remove outliers. In addition to water temperature, the data providers supplied detailed information of the lake depth and hypsometric data to characterize the morphometry of lake basins, which are required as input to most of the lake models.

\subsubsection{ISIMIP2b}

ISIMIP2b was designed to compare lake responses to simulated historical and projected future climates relative to pre-industrial climates with a focus on improving the understanding of the effects of global warming in the range of $1.5^{\circ} \mathrm{C}$ to $2^{\circ} \mathrm{C}$ (Frieler et al. 2017). The lake ensemble included simulations forced by bias-adjusted data from four GCMs, covering historical and up to three Representative Greenhouse Gas Concentration Pathways (RCPs): a low (RCP2.6), mediumhigh (RCP6.0), and high emission scenario (RCP8.5). The past and future responses of lakes from these simulations were compared to simulations forced by bias-adjusted pre-industrial control (picontrol) climate data from the same four GCMs to quantify differences from pre-industrial conditions. These differences can be thought to represent the "pure" effect of ongoing changes in climate on simulated lake water temperatures, with minimal confounding effects from changes in further human influences that were identical between the two sets of simulations.

Climate input data for ISIMIP2b were derived from four GCMs, namely GFDL-ESM2M, HadGEM2-ES, IPSL-CM5A-LR, and MIROC5 (Taylor et al., 2012; Frieler et al., 2017) that were available from CMIP5. These GCM results had a wide range of projected warming rates, with GFDL-ESM2M and HadGEM2-ES representing the lower and higher ends of the warming spectrum, respectively. The data management team at the Potsdam Institute for Climate Impact Research (PIK) bias-adjusted the GCM data with a reference dataset of atmospherics observations (EWEMBI, Lange, 2019a) using the statistical transfer functions by Hempel et al. (2013) modified

25 to correct known biases in modelled variables (Frieler et al., 2017). The bias correction was aimed at preserving trends and distributions of modelled variables relative to observed atmospheric 
observations. All meteorologic data, except horizontal wind components were bias corrected. The list of output meteorological variables from GCMs that were used to drive the lake models can be found in Table 2.

Lake Sector simulations followed the ISIMIP2b protocol (Fig. 1, Frieler et al., 2017, 5 https://www.isimip.org/protocol/\#isimip2b). To estimate the effects of historical climate warming, lake model simulations forced with data from historical based emission scenarios were compared with simulations forced with the picontrol scenario. Likewise, to evaluate future climate impacts, lake model simulations were forced with data from the RCP trajectories (RCP2.6, RCP6.0, and RCP8.5) and compared to results from simulations forced with picontrol. The timespans of different

10 climate change scenarios were 1661-1860 (picontrol), 1861-2005 (picontrol and historical), 20062099 (picontrol, RCP2.6, RCP6.0, and RCP8.5). An extended period between 2100 and 2299 was also used for simulations based on available results for specific emission scenarios (picontrol emissions, RCP2.6) to evaluate longer-term changes in global temperature that meet the Paris Agreement objectives (Frieler et al., 2017).

15 Since the lake modelling strategy was specifically designed to evaluate only thermal changes resulting from changing atmospheric conditions under the assumption of no watershed inputs (constant lake level), the simulations are not influenced by any changes in land use or socioeconomic conditions that would affect watershed inputs to the lakes or changes driven by changes in lake trophic status. The pre-industrial reference simulations (picontrol emissions) assumed fixed socio-economic conditions and land use (1660-1860). CLM4.5 provides additional sets of simulations according to protocols for other ISIMIP sectors (i.e., biomes, agriculture, water (global), permafrost) with a combination of socio-economic (1860-soc and 2005-soc) and $\mathrm{CO}_{2}$ fertilization (2005-co2) scenarios. Lake temperature simulations that were a component of CLM4.5 did not account for these additional scenarios. 


\subsubsection{ISIMIP 3a and $b$}

The protocol for the third simulation round of ISIMIP3, which is currently ongoing, is largely similar to the ISIMIP2 protocol, but includes counterfactual climate forcing in ISIMIP3a, and the next generation (CMIP6) of climate model forcing and various emission scenarios in ISIMIP3b.

5 Below, we highlight the main differences between both simulation rounds.

In ISIMIP3a, the observational climate forcing covers the period 1901-2016 and consists of the Global Soil and Wetness Project version 3 (GSWP3; Dirmeyer et al., 2006), homogenized to W5E5 for the period 1901-1978 (Lange, 2019a) and a combination of the W5E5 dataset (Lange, 2019b, Cucchi et al., 2020) for the period 1979-2016 and GSWP3 before that. This observational dataset was bias-corrected using observations from Global Precipitation Climatology Centre (GPCC) (more details at https://climatedataguide.ucar.edu/climate-data/gpcc-global-precipitationclimatology-centre) and Climatic Research Unit (CRU) (more details at https://crudata.uea.ac.uk/cru/data/hrg/) using the method outlined in Lange (2019b). In addition to providing data for the evaluation and calibration for local lake models, ISIMIP3a provides counterfactual climate forcing, which is a detrended version of the historical climate forcing (Mengel et al., 2021). Models driven by the counterfactual climate and other historical human pressures provide a baseline to compare with to determine climate change impacts. In ISIMIP3b, the climate forcing is updated to include the next generation of CMIP6 simulations, which were bias-corrected with a new adjustment routine correcting the simulations towards the W5E5 observational data (https://www.isimip.org/gettingstarted/isimip3b-bias-correction/). Climate simulations from five GCMs were provided, namely GDFL-ESM4, UKESM1-0-LL, MIP-ESM12-HR, IPSL-CM6A-LR and MRI-ESM2-0. In addition to the picontrol and historical emission simulations, the future simulations include the SSP1-RCP2.6, SSP3-RCP7 and SSP5-RCP8.5 emission pathway scenarios. Following the CMIP6 protocol, the simulation periods were updated to 1601-1849 for pre-industrial, 1850-2014 for historical and 2015-2100 for future simulations. 


\subsubsection{Climate data availability}

All bias-adjusted meteorologic forcing data provided by ISIMIP sectors have a daily temporal resolution and $\mathrm{a} 0.5^{\circ} \times 0.5^{\circ}$ spatial (i.e., $\sim 50 \mathrm{~km}$ at the equator) resolution. Data are publicly accessible at the DKRZ server at PIK for registered ISIMIP users, and at the ISIMIP data repository (https://data.isimip.org/) for all others. While most models in the Lake Sector performed simulations at daily time steps, some models required temporally disaggregated forcing data at subdaily time steps. The modelling teams performed temporal disaggregation using their customary approaches (see more details in Section 4). For simulations in the local domain, data were extracted for grid cells corresponding with the lakes' geographic locations. No further downscaling or local corrections were applied to ensure consistency in the forcing data applied to all local lakes.

\subsection{Lake parameterization}

To account for variations in individual lake responses to meteorological drivers (Kraemer et al., 2015, Shatwell et al., 2019, Heiskanen et al., 2015), there were only two types of data needed by the lake models: a description of the lake bathymetry and information on the lake water transparency, necessary for estimating the diffuse attenuation coefficient of incoming shortwave radiation.

\subsubsection{Bathymetry}

Most lake hydrodynamic models require the hypsographic relationship between depth and surface area, which is critical for determining layer volumes and storage and the vertical transfer of heat. Data providers supplied these bathymetric data for each lake in the local domain. The two versions of air2water versions did not require information on lake bathymetry.

In the global domain, the bathymetry of the representative lakes in each $0.5^{\circ} \times 0.5^{\circ}$ grid cell was derived from a rasterized version of the Global Lake and Wetland Database (Lehner and Doll, 2004; 
Toptunova, 2019) for ISIMIP2 and derived from the HydroLAKES database (Messager et al., 2016) for ISIMIP3. For each grid cell, the average lake depth and lake surface area values for all the lakes in the grid cell were computed. In the case of the LAKE model, both surface area and mean depth of global lakes were obtained from GLDBv2 (Choulga, 2014). For all of the lake models, a cylindrical shape was assumed to represent lake bathymetry. The gridded lake masks for the surface area and mean depths can be accessed online (https://data.isimip.org/).

\subsubsection{Water transparency}

Water transparency may mediate a lakes' response to climate change (Butcher et al., 2015, Magee et al., 2016, Shatwell et al., 2019). The attenuation coefficient $\left(\mathrm{K}_{\mathrm{d}}, \mathrm{m}^{-1}\right)$ of shortwave radiation is a key parameter to describe water transparency in the lake models (Potes et al., 2012). In all simulations, single non-varying values of $\mathrm{K}_{\mathrm{d}}$ were used.

For simulations in the local domain, multi-season and multi-year water transparency data were available from 49 lakes that were used to calculate a diffuse attenuation coefficient $\left(\mathrm{K}_{\mathrm{d}}\right)$ value or a mean Secchi depth $\left(Z_{S D}, m\right)$ (Table $\left.S 1\right)$. When only $Z_{S D}$ measurements were available, $K_{d}$ was estimated at $1.7 / Z_{\mathrm{SD}}$. If both mean $\mathrm{Z}_{\mathrm{SD}}$ and $\mathrm{K}_{\mathrm{d}}$ were provided, the directly measured $\mathrm{K}_{\mathrm{d}}$ was used. When both $\mathrm{K}_{\mathrm{d}}$ and $\mathrm{Z}_{\mathrm{SD}}$ were lacking, we approximated $\mathrm{Kd}$ as a function of mean lake depth following the equation derived for 88 Swedish lakes (Hakanson et al., 1995)

$$
\mathrm{K}_{\mathrm{d}}=1.1925^{*} \max (\text { mean_depth, } 1)^{\wedge}{ }^{-0.424}
$$

Or from maximum depth following the expression derived for 1,258 global lakes (Woolway et al. 2021):

$$
\mathrm{K}_{\mathrm{d}}=5.681 * \max \left(\max \_ \text {depth, } 1\right)^{\wedge}-0.795
$$


For ISIMIP2a, the different modelling teams defined the best method to parameterize transparency based on the specific lake model requirements and previous protocols developed for calibration and simulation with any given model. Consequently, transparency parameterizations varied both with lake models and the spatial domain of simulations. In the local domain, measured $\mathrm{K}_{\mathrm{d}}$ values derived from $Z_{\mathrm{SD}}$ or Hakanson's expression were used in ALBM, Simstrat, and GLM, whereas FLake runs adopted the approach outlined in Woolway et al (2021). In GOTM and MyLake, the mean $\mathrm{K}_{\mathrm{d}}$ was determined in the calibration process. The two air2water models did not require water transparency. In the global scale simulations, the grid-varying mean depths of the lakes were used to estimate $\mathrm{K}_{\mathrm{d}}$ values from Hakanson's expression in all lake models except for VIC-LAKE. This estimation process is also in the CLM4.5 (Oleson et al., 2013). In the VIC-LAKE model, two-band (visible and near-infrared) Beer's law radiation constants were used to parameterize transparency (Bowling and Lettenmaier, 2010).

\subsubsection{Water balance}

The water balance and/or water inputs and withdrawals were not considered in the ISIMIP2a-b simulation rounds to simplify the setup and execution of the temperature simulation for lakes that were not expected to undergo large seasonal fluctuations in water level. The formulations of some lake models (e.g., air2water or FLake) do not explicitly include hydrological balances. Additionally, the precipitation and evaporation component of water mass exchange was switched off (i.e., only heat exchange occurred) or compensated with a closure term (e.g., CLM4.5) in all models. We acknowledge that omission of water balance (water inputs and outputs) may have a significant impact on the simulated climate change impacts in the seven lakes or reservoirs with large water level fluctuations (Table 1), thus caution should be used when evaluating the results for these lakes. 


\subsection{Calibration of local lake models in ISIMIP2a}

Eight lake models had specific parameters and coefficients calibrated based on what each modelling group felt was appropriate for use with their specific lake model (Table 3). Each modelling group defined reasonable coefficient ranges based on past experience and the physical constraints that would set limits on the parameter and coefficient values. For each model, the same calibration routine and objective function was applied to all lakes in the local domain. Different objective functions (e.g., RMSE, NSE, Pearson r; see Table S2) were adopted by the different models. In all cases the model performance was optimized by minimization of the difference between simulated and measured water temperature.

10 The number of calibrated parameters and coefficients in a specific model ranged from one (FLake) to nine (ALBM, Table 3). The calibrated coefficients were mostly related to processes controlling surface heat and energy fluxes, turbulent kinetic energy and wind stress, and light attenuation. Other calibrated coefficients for specific processes were model-specific, including sediment structure and heat fluxes (ALBM), seiches (Simstrat), and ice/snow energy fluxes (MyLake, Simstrat). To allow for comparing the lake models' performance in predicting measured water temperature, for all lake models two common metrics of model fit were calculated in post-processing (not necessarily coincident with the calibration metrics): the root-mean-square error (RMSE) and coefficient of determination (R2, Table 3).

\subsection{Long-term simulations in ISIMIP2b}

The ensemble of lake models in both the local and global domains was forced with the biascorrected GCM outputs for the no-climate-change, historical, and future climate change scenarios (picontrol, historical, RCP2.6, RCP6.0, RCP8.5). When running the long-term simulations, the calibrated models for each lake were used, so that each model was optimized for that lake based on the historical calibration described in section 3.6 above. Spin-up periods used with the local lake models varied and were dependent on the protocols and experience of each modelling group (Table 
S2). When a spin-up period was used, the spin-up data were created either by repeating the initial year(s) of the scenario input data, and then adding these duplicate data to the beginning of the forcing data, or by using a portion of the historical scenario to spin-up future scenario simulations. Initial conditions used for water temperature profiles in the local lake simulations also varied with model and geographical location and were based on either observed temperature profiles, an assumed isothermal $4^{\circ} \mathrm{C}$ profile, or related to the mean annual air temperature at the local lake location. A more detailed description of the modelling workflows that were used to spin-up and initialize each model in the local domain is given in Table S2.

For simulations in the global domain, most lake models used parameter and coefficient values that

were set according to previous experience with each model: For GOTM, the average values of calibrated coefficients from the GOTM local lakes (Table 3) and default values for the coefficients that were not calibrated (Umlauf 2005 manual, Sachse et al., 2014) were used. Similarly, the methods for spinning up the models in the Global Domain also varied depending on the practices applied by each modelling group. Groups working in the global domain tended to use longer spin up periods and to use data from either the picontrol or historical scenarios to create the spin up data that were added to the scenario forcing data. The initial water temperature profiles used in the global lake simulations also varied. In some cases, the models were initialized as homogenous profiles often based on the mean annual air temperature or linear profiles based on the mean annual air temperature and an assumed $4^{\circ} \mathrm{C}$ bottom temperature, or linear profiles using a fixed surface and bottom temperature. A description of the modelling workflows that were used to spin-up and initialize each model in the global domain is given in Table S3. More detailed model-specific simulation set-ups can also be found at https://www.isimip.org/impactmodels/.

\subsection{Output data format}

25 All outputs from the models were aggregated to daily averages (Table 4, Table S4). The vertical resolution of the simulated water temperature profiles in the local domain was reported at $0.5 \mathrm{~m}$ 
intervals for lakes with $<50 \mathrm{~m}$ maximum depth and at $1 \mathrm{~m}$ intervals for lakes $>50 \mathrm{~m}$. However, the vertical resolution of simulated temperatures in the global domain was limited by file storage capacity. The number of reported layers depended on the depth of the representative lake and ranged from 1 to 13 (GOTM, LAKE, Simstrat-UoG), from 1 to 50 (ALBM) and from 1 to 1000 (VIC-

5 LAKE). Output from CLM4.5 was grid-invariable, representing water temperature in 10 layers. The remainder of reported variables (thermodepth, surftemp, bottemp represented a single value, which was either calculated using the approach presented in the simulation protocol; see https://www.isimip.org/protocol/2b/) or was directly outputted by the lake model (Table 4, Table S4). The Lake Sector simulation protocol provides the model performance metrics used during calibration of lakes in the local spatial domain (Table 3). A full list of variables simulated within ISIMIP2b is summarized in Table S4.

\section{Results and discussion}

\subsection{Results from ISIMIP2a}

\section{4.1.1. Calibration and performance of local lake models}

The simulated water temperatures from the calibrated lake models compared well to the measured water temperature data. Based on the simulation data from 62 lakes, a robust fit for all eight local lake models was found, with a multi-model mean $\mathrm{RMSE}$ of $1.50^{\circ} \mathrm{C}$ that ranged from $0.98^{\circ} \mathrm{C}$ (air2water6par) to $2.41^{\circ} \mathrm{C}$ (FLake, Table 3). The coefficients of determination ( $\mathrm{r} 2$ ) ranged from 0.59

20 (MyLake) to 0.96 (air2water6par), with the multi-model average value of 0.84 . The lake models predicting surface water temperature, air2water4par and air2water6par, as would be expected, showed lower prediction errors compared to the lake models predicting full water temperature profiles. While the multi-model mean goodness of fit was reasonable for most lakes, $16 \%$ of lakes showed RMSE larger than $2^{\circ} \mathrm{C}$, indicating less certain predictions (Table 3, Table S1). For 
individual models, the number of lakes with RMSE exceeding $2{ }^{\circ} \mathrm{C}$ varied from 3 lakes $(5 \%$, air2water4par) to 40 lakes (65\%, FLake).

Although the ISIMIP2a forcing data used a daily time step and a $0.5^{\circ}$ spatial resolution, the prediction errors in water temperature were relatively small (Table 3) even though these input data are, in general, less than optimal for the simulations of individual lakes (Bruce et al., 2018). An exception is the air2water model that, owing to its statistical data-driven calibration of model's parameters has been shown to be able to provide the same projections irrespective of the nature of the air temperature dataset used to drive the model (Piccolroaz et al., 2018). The average errors in the prediction of water temperature observations were comparable with previous multi-model and/or multi-site modelling studies, where the mean RSME in water temperature predictions ranged from $1.10^{\circ} \mathrm{C}$ to $2.79^{\circ} \mathrm{C}$ (Stepanenko et al., 2013, Winslow et al., 2017, Bruce et al., 2018, Piccolroaz et al., 2020). Similarly, the prediction of epilimnetic temperature showed lower errors compared to predictions of hypolimnetic temperature (Winslow et al., 2017, Bruce et al., 2018).

The calibration of the local lake models also has implications for simulations of lakes in the global domain. Three local lake models (ALBM, GOTM, Simstrat) were also used as global models, therefore the ranges of the calibrated parameters $\mathrm{c}$ be used to constrain the parameterization of global simulations in future ISIMIP simulation rounds (Gao et al., in review). This is particularly important in view of the greater uncertainty in the global domain results (Vanderkelen et al., 2020; Woolway et al., 2021; Grant et al., 2021) and the lack of global data products to calibrate global lake models.

\subsubsection{Model response to observational vs simulated forcing data}

In addition to simulations using ISIMIP2a forcing, the ALBM and FLake models were also used for simulations forced by EWEMBI observational data (1979-2016). This will allow for assessment of the difference in model output when used with observational forcing data compared to simulations with GCM forcings during the historical time period. Given that impacts under past and future climates are modelled with bias-adjusted GCMs, a comparison with simulations using the 
observed data used for bias correction will allow an assessment of how simulations forced with the GCM historical inputs compare with those forced using observed (historical) climate (see also Piccolroaz et al., 2018 for a similar analysis). This can give an estimate of the uncertainty in the ISIMIP GCM scenarios and the bias correction method. There are so far no studies for this application of the ISIMIP2a simulations, but the existing simulation outputs archive are publicly accessible and hold potential for further study.

\subsection{Results from ISIMIP2b}

\subsubsection{Impacts of past and future climate change on lakes}

10 Time-series of ensemble simulations of lake surface temperature for local lakes over the historical (1851-2005) and future (2006-2100) periods are shown in Figure 2a. Each ensemble combines the results from 62 well-studied lakes and three separate calibrated lake models. Mean annual surface water temperatures increased by $0.15^{\circ} \mathrm{C}$ at the end of the historical period (present-day, 1976-2005) relative to the pre-industrial control. These simulations support in situ observations that lakes across

15 the globe are already warming (Woolway et al., 2020; O’Reilly et al., 2015). Future projections (2006-2099) accounting for low (RCP2.6) to high (RCP8.5) greenhouse gas emissions under present-day socio-economic conditions, provide ensemble estimates of warming of $1.38^{\circ} \mathrm{C}, 2.46^{\circ} \mathrm{C}$ and $3.85^{\circ} \mathrm{C}$ by the end of the century (2070-2099) relative to pre-industrial control, respectively (Fig. 2a). For example, the strong mitigation measures associated with RCP2.6 resulted in lake

20 surface temperature remaining below the $2^{\circ} \mathrm{C}$ anomaly. The ensemble predictions provide a consistent projection of a slower surface water warming under RCP2.6, starting at mid-century (Fig. 2a) than for other greenhouse gas emission scenarios.

Based on the anomalies between the pre-industrial control and future scenarios, all lake models showed similar warming rates and trajectories of change. However, the GOTM local simulations were on average $1.75^{\circ} \mathrm{C}$ warmer than simulations from ALBM and Simstrat, probably because the version of GOTM used for the local lake simulations had only a very rudimentary description of 
the effects of lake ice on surface heat exchange. These results show the importance of using an ensemble of models to increase the robustness of simulated past and future changes and making interpretations less dependent on a single or small suite of the lake models used (Trolle et al., 2014). The common fundamental output from all lake models was water temperature, and for most models, this output is in the form of a full vertical profile at a daily time step. These data and other related model output were also aggregated to different metrics describing lake hydrodynamics, e.g., thermocline depth, the onset of stratification, energy and heat fluxes at the air-water interface, and lake ice characteristics and dynamics (Table 4). The methods to calculate these metrics are defined in the Lake Sector protocol (https://www.isimip.org/protocol/), and for additional metrics, the full

10 lake water temperature profiles can be further processed by users.

The average changes in surface and bottom water temperature for the 62 lakes for the RCP8.5 greenhouse gas emission scenario, using the GOTM model forced by the four GCM outputs are shown in Figure 2b. Results from the ensemble simulations of the local lakes' future responses show faster warming of surface waters (local-lake mean $4.08^{\circ} \mathrm{C}$ ) than bottom waters $\left(1.49^{\circ} \mathrm{C}\right)$ by 2070-2099. On average, the difference between surface and bottom water temperature anomaly was $2.6^{\circ} \mathrm{C}$. There was a wide range of lake responses in the local domain (Figure $2 \mathrm{~b}$ ), with an average range in the change in surface temperatures anomalies derived from the ensemble of $2.28^{\circ} \mathrm{C}$ and bottom temperature of $3.22^{\circ} \mathrm{C}$. These results are consistent with previous findings of the diverse responses in lake surface temperature across the globe (O'Reilly et al., 2015; Pilla et al., 2020) depending on a complex interaction of climate regions (Piccolroaz et al., 2020), lake morphology (Toffolon et al., 2014), and atmospheric conditions (Spence, 2013), and changes in the responses in bottom temperatures being influenced by the lake's morphometric characteristics (Kraemer et al., 2015). The Lake Sector local domain provides information on the lake-specific characteristics related to morphometry and water transparency (Table S1) to enable investigation of how the observed differences in responses to climate warming is influenced by lake characteristics.

The variability in Figure $2 b$ is a result of both variable lake responses and the differences in the forcing associated with the four GCMs. The mean change in surface water temperatures under 
RCP8.5 until the end of the 21 st century ranged from $2.39^{\circ} \mathrm{C}$ (when forced by GFDL-ESM2M) to $5.34^{\circ} \mathrm{C}$ (when forced by IPSL-CM5A-LR). A similar pattern was observed for bottom temperature, although the differences were less pronounced $\left(1.19-1.78^{\circ} \mathrm{C}\right)$. The changes in the mean surface temperature followed the differences in the air temperature projected by the four GCMs. Sorted from colder to warmer based on simulated impacts on air and water temperature on the local lakes, the GCMs are ranked in the order of GFDL-ESM2M, MIROC5, HADGEM2-ES, and IPSL-CM5ALR. Similar differences were observed in water temperature and ice changes by Woolway et al. (2019). These results indicate that the choice of the GCM has a large effect on the changes predicted by the lake models. Using outputs from several GCMs, following the ISIMIP protocols, therefore,

provides the advantage of including ensemble forcing data in simulations of climate change impacts on lakes, increasing the robustness of predictions.

The results of global domain simulations made with the GOTM model are shown in Figure S1 for three greenhouse gas emission scenarios and as an ensemble of four GCMs. Under RCP2.6, the emission scenario with the strongest mitigation measures, the global mean annual lake surface temperature was projected to be $12.7^{\circ} \mathrm{C}$ (range: $3.8-29.4^{\circ} \mathrm{C}$ ) by the end of the 21 st century (Figure $2 \mathrm{C}$, Fig. S1a). However, global mean lake surface temperatures of $13.4^{\circ} \mathrm{C}\left(4.2-30.4^{\circ} \mathrm{C}\right)$ and $14.3^{\circ} \mathrm{C}$ $\left(4.8-31.6^{\circ} \mathrm{C}\right)$ were projected for the medium-high emission (RCP6.0) or high-end emission scenario (RCP8.5), respectively (Figure S1c, e). Mean annual lake temperature were projected to increase by $0.9^{\circ} \mathrm{C}\left(0.53-1.32^{\circ} \mathrm{C}\right), 1.7^{\circ} \mathrm{C}\left(1.0-2.3^{\circ} \mathrm{C}\right)$, and $2.6^{\circ} \mathrm{C}\left(1.6-3.6^{\circ} \mathrm{C}\right)$ under these three greenhouse gas emission scenarios relative to the pre-industrial control (Fig. S1b, d, f). Simulations in the global domain allowed the documentation and visualization of spatial variations in lake thermal structure that are simply not possible using geographically constrained data in the local domain. The most pronounced spatial pattern was a latitudinal gradient of warming of global lakes (Fig. 2C, Fig. S1). These results corroborate previous global-scale modelling studies, although here the results are based on ensemble simulations compared to single model simulations. 


\section{Conclusions}

Modelling the impact of climate change at a global scale using an ensemble of lake models requires data, vision, ambition, and a strong collaborative network of researchers from a range of disciplines. The first ensemble model simulations in the Lake Sector of the Inter-Sectoral Impact Model Intercomparison Project (ISIMIP), has leveraged such a network to design and execute a protocol that has now provided state-of-the-art scientific evidence of climate change impacts on lakes under low to high greenhouse gas emission scenarios. The Lake Sector protocol in the local domain allows for the calibration of lake models forced with historical ISIMIP2a inputs and parametrized using site-specific data of bathymetry. Comparison of simulated and measured water temperature from 62 well-studied lakes facilitated detailed calibration and evaluation of the models in the local domain and suggested reasonable parameter and coefficient values for the uncalibrated models that were used in the global domain. Simulations in the global domain provided daily outputs of lake thermal conditions at a consistent $0.5^{\circ} \times 0.5^{\circ}$ global grid resolution.

Our simulations at both the local and global resolution quantify past and future changes in water temperature, energy and heat fluxes, and ice in unprecedented geographical coverage. Simulations by the ISIMIP Lake Sector also provide previously unattainable opportunities to evaluate the levels of uncertainty in simulations related to the differences in forcing data between reanalyses, GCMs, emission scenarios, and in model structure and parameterization among lake models.

Simulations by the ISIMIP Lake Sector have and will continue to estimate the range and robustness

of plausible lake responses to global warming either at $1.5^{\circ} \mathrm{C}$ above pre-industrial levels as defined by the ISIMIP2b protocol or for any other future greenhouse gas emission scenarios. This work furthers the state-of-the-art in freshwater science (Vanderkelen et al., 2020; Grant et al., 2021; Woolway et al., 2021).

Here, we have described the first stage of simulations undertaken by the ISIMIP Lake Sector, which were performed under the simplifying assumption that hydrologic inputs from the lake watershed had minimal effects on the simulated thermal structure. While this is a reasonable assumption for lake hydrodynamic simulations, it will clearly not be the case for simulations of lake 
biogeochemistry and ecology that will strongly depend on the nutrient inputs from the lake watershed. Within the ISIMIP framework, the simulated climate change impacts are (inter-) comparable with results from 13 other sectors, supporting cross-sectoral aggregation of impacts (Vanderkelen et al., 2020). Ultimately, we expect that the improved simulations of lake hydrodynamics presented here will form a robust basis for more complex simulations of water quality, lake level fluctuations, and other greenhouse gas emissions scenarios in upcoming simulation rounds, where lake water quality models can be coupled to the hydrologic and biogeochemical outputs from other sectors of the ISIMIP.

\section{Code and data availability}

10 The simulation protocol used in the Lake Sector of the ISIMIP2a-b and ISIMIP3a-b simulation rounds has no common code associated with it. The source codes for specific models are either publicly available or can be requested from the model leaders. A full list of models is available at https://Www.isimip.org/impactmodels. Input to the models for ISIMIP2b can be found here: https://data.isimip.org/, for ISIMIP3a here: https://doi.org/10.48364/isimip.263794 and for

15 ISIMIP3b here: https://doi.org/10.48364/isimip.383948. All publicly available primary and secondary input and models' output data are publicly available at https://data.isimip.org/ and data availability status is continuously updated.

\section{Author contributions}

M.G., W.T., R.M., D.P. coordinate the lake sector, with key contributions over the past years of I.V., D.M., R.I.W., L.G. and E.J.. J.S., F.Z., K.F., and M.Me. are part of the ISIMIP core team, provided the meteorological input data, and liaise the lake sector with the whole project. M.G., W.T., D.M., R.I.W., V.Y.B., D.B., R.-M.C., A.V.B., B.D., G.G., M.G., A.B.G.J., G.K., R.L., M.Ma., T.M., M.P., S.P., L.R.V., M.S., T.S., V.M.S., Z.T., and H.Y. conducted the lake model simulations. W.T., D.B., R.-M.C., G.G., G.K., M.Ma., T.M., M.S., H.Y., R.A., M.A., O.A., L.A., 
K.A., L.B., C.C., K.C., E.d.E., C.D., M.G., J.H., K.J., I.D.J., A.L., E.B.M., I.M., H.M., C.M., D.O., M.P., K.R., D.R., J.R., R.S., L.v.d.L., P.V., D.W., N.K.W., S.W., G.Z. provided in-situ lake calibration data. All co-authors read the manuscript and provided comments.

\section{Competing interests}

5 The authors declare that they have no conflict of interest.

\section{Acknowledgements}

We thank and acknowledge the support of Stefan Lange, Matthias Büchner, and Iliusi Vega del Valle for their roles in producing, coordinating, and making available the ISIMIP climate scenarios.

10 We also thank Jorrit Mesman for enabling ISIMIP3 simulations through LakeEnsembleR. The funds from the WATExR project (ERA4CS, JPI Climate) provided the financial support to M.G., R.M., D.P.T.M., A.F.E.J. and D.M. The computations and data handling were enabled by resources provided by the Swedish National Infrastructure for Computing (SNIC) at Uppmax partially funded by the Swedish Research Council through grant agreement no. 2018-05973. M.G. thanks Marcus Lundberg and Douglas Scofield at Uppmax for their assistance with codes optimisation and software installation, which was made possible through application support provided by SNIC. I.V. is a research fellow at the Research Foundation Flanders (FWOTM920). Z.T. is supported by the US DOE's Earth System Modeling program through the Energy Exascale Earth System Model (E3SM) project. A.B.G.J. is supported by the NWO talent grant Veni (project number VI.Veni.194.002). B.D. is supported by the Wageningen Institute for Environment and Climate Research (WIMEK; Grant No. 5160957551). H.M. was funded by Department of Public Technology, at Mälardalen University, ABB Västerås, Västmanlands Avfallsaktiebolag, Eskilstuna Energi \& Miljö and the EU REFLECT project (Response of European Freshwater Lakes to 
Environmental and Climatic Change, Contract No. ENV4-CT97-0453). J.H. acknowledges support from the ERDF/ESF project Biomanipulation as a tool for improving water quality of dam reservoirs (no. CZ.02.1.01/0.0/0.0/16_025/0007417). Partial funding for this work was provided by the Israeli Ministry of Energy grant \# 215-17-017. High frequency data from Windermere and Esthwaite Water is currently funded by the UK Natural Environment Research Council as part of the UK-SCAPE programme (refNE/R016429/1). H.Y. and J.R. were supported by the Ontario Ministry of the Environment, Conservation and Parks. R.L. was supported through an NSF ABI development grant (\#DBI 1759865). V.S. is partially supported by Russian Ministry for Higher Education and Science (contract No. 075-15-2021-1399). ISIMIP data preparation and curation is supported by the German Federal Ministry Ministry of Education and Research (BMBF) under the research project (ISI-Access, 16QK05). Data from Lakes Annecy, Bourget and Geneva is collected and stored with support from the (C) OLA-IS, AnaEE-France, INRAE of Thonon-les-Bains, CIPEL, SILA and CISALB (Rimet et al. 2020, https://doi.org/10.4081/jlimnol.2020.1944). Data from Lake Kivu was collected with support from Jean-Pierre Descy and the Belgian Science Policy Office through the research project EAGLES (CD/AR/02A). The Archbold Biological Station, Evelyn Gaiser, Vivienne Sclater, and Monika LaPlante are thanked for sharing the data on Lake Annie. A.L. and data collection from Estonian lakes was funded by Estonian Research Council grants PSG32, PRG709 and PRG1167. Data from Lake Burley Griffin was collected by the National Capital Authority, Canberra, Australia.

\section{References}

Ayala, A. I., Moras, S., \& Pierson, D. C. (2020). Simulations of future changes in thermal structure of Lake Erken: proof of concept for ISIMIP2b lake sector local simulation strategy. Hydrology and Earth System Sciences, 24(6), 3311-3330. 
Balsamo, G., Salgado, R., Dutra, E., Boussetta, S., Stockdale, T., \& Potes, M. (2012). On the contribution of lakes in predicting near-surface temperature in a global weather forecasting model. Tellus A: Dynamic Meteorology and Oceanography, 64(1), 15829.

5 Bowling, L. C., \& Lettenmaier, D. P. (2010). Modeling the effects of lakes and wetlands on the water balance of arctic environments. Journal of Hydrometeorology, 11(2), 276-295.

Bruggeman, J., \& Bolding, K. (2014). A general framework for aquatic biogeochemical models. Environmental modelling \& software, 61, 249-265.

Burchard, H., \& Bolding, K. (2001). Comparative analysis of four second-moment turbulence closure models for the oceanic mixed layer. Journal of Physical Oceanography, 31(8), 1943-1968.

Butcher, J. B., Nover, D., Johnson, T. E., \& Clark, C. M. (2015). Sensitivity of lake thermal and mixing dynamics to climate change. Climatic Change, 129(1), 295-305.

Carpenter, S. R., Stanley, E. H., \& Vander Zanden, M. J. (2011). State of the world's freshwater ecosystems: physical, chemical, and biological changes. Annual Review of Environment and Resources, 36, 75-99.

Choulga, M., Kourzeneva, E., Zakharova, E., \& Doganovsky, A. (2014). Estimation of the mean depth of boreal lakes for use in numerical weather prediction and climate modelling. Tellus A: Dynamic Meteorology and Oceanography, 66(1), 21295.

Choulga, M., Kourzeneva, E., Balsamo, G., Boussetta, S., \& Wedi, N. (2019). Upgraded global mapping information for earth system modelling: an application to surface water depth at the ECMWF. Hydrology and Earth System Sciences, 23(10), 4051-4076. 
Cucchi, M., Weedon, G. P., Amici, A., Bellouin, N., Lange, S., Müller Schmied, H., Hersbach, H. and Buontempo, C. (2020) WFDE5: Bias-adjusted ERA5 reanalysis data for impact studies, Earth System Science Data, 12(3), 2097-2120.

Dirmeyer, P. A., Gao, X., Zhao, M., Guo, Z., Oki, T. and Hanasaki, N. (2006) GSWP-2: Multimodel Analysis and Implications for Our Perception of the Land Surface, Bulletin of the American Meteorological Society, 87(10), 1381-1398

10 Frieler, K., Lange, S., Piontek, F., Reyer, C. P., Schewe, J., Warszawski, L., ... \& Yamagata, Y. (2017). Assessing the impacts of $1.5 \mathrm{C}$ global warming-simulation protocol of the Inter-Sectoral Impact Model Intercomparison Project (ISIMIP2b). Geoscientific Model Development, 10(12), 4321-4345.

15 Gädeke, A., Langer, M., Boike, J., Burke, E.L., Chang, J., Head, M., Reyer, C.P.O., Schaphoff, S., Thiery, W., Thonicke, K., Climate change reduces future winter tundra travel across the Pan-Arctic even under low-end global warming scenarios, Environmental Research Letters, 16(2), 024049.

Gal, G., Gilboa, Y. Schachar, N., Estroti, M., \& Schlabing, D. (2020). Ensemble Modeling of the Impact of Climate Warming and Increased Frequency of Extreme Climatic Events on the Thermal Characteristics of a Sub-Tropical Lake. Water 12(7): 1982

Gaudard, A., Råman Vinnå, L., Bärenbold, F., Schmid, M., \& Bouffard, D. (2019). Toward an open access to high-frequency lake modeling and statistics data for scientists and practitioners-the case of Swiss lakes using Simstrat v2. 1. Geoscientific Model Development, 12(9), 3955-3974. 
Goudsmit, G. H., Burchard, H., Peeters, F., \& Wüest, A. (2002). Application of k-€ turbulence models to enclosed basins: The role of internal seiches. Journal of Geophysical Research: Oceans, 107(C12), 3230.

5 Grant, L., Vanderkelen, I., Gudmundsson, L., Tan, Z., Perroud, M., Stepanenko, V. M., ... \& Thiery, W. (2021). Attribution of global lake systems change to anthropogenic forcing. Nature Geoscience, 14(11), 849-854.

Gudmundsson, L., Boulange, J., Do, H. X., Gosling, S. N., Grillakis, M. G., Koutroulis, A. G., 10 Leonard, M., Liu, J., Müller Schmied, H., Papadimitriou, L., Pokhrel, Y., Seneviratne, S. I., Satoh, Y., Thiery, W., Westra, S., Zhang, X., Zhao, F., Globally observed trends in mean and extreme river flow attributed to climate change, Science, 371, 1159-1162.

Guo, M., Zhuang, Q., Tan, Z., Shurpali, N., Juutinen, S., Kortelainen, P., \& Martikainen, P. J. 15 (2020). Rising methane emissions from boreal lakes due to increasing ice-free days. Environmental Research Letters, 15(6), 064008.

Guo, M., Zhuang, Q., Yao, H., Golub, M., Leung, L.R., Pierson, D., \& Tan, Z. (2021). Validation and Sensitivity Analysis of a 1-D Lake Model across Global Lakes. Journal of Geophysical Research: Atmospheres, 126, e2020JD033417.

Guseva, S., Bleninger, T., Jöhnk, K., Polli, B.A., Tan, Z., Thiery, W., Zhuang, Q., Rusak, J., Yao, H., Lorke, A., Stepanenko, V., 2020, Multimodel simulation of vertical gas transfer in a temperate lake, Hydrology and Earth System Sciences, 24, 697-715. 
Heiskanen, J. J., Mammarella, I., Ojala, A., Stepanenko, V., Erkkilä, K. M., Miettinen, H., ... \& Nordbo, A. (2015). Effects of water clarity on lake stratification and lake-atmosphere heat exchange. Journal of Geophysical Research: Atmospheres, 120(15), 7412-7428.

Hansen, G. J., Read, J. S., Hansen, J. F., \& Winslow, L. A. (2017). Projected shifts in fish species dominance in Wisconsin lakes under climate change. Global Change Biology, 23(4), 1463-1476.

Henderson-Sellers, B. (1985). New formulation of eddy diffusion thermocline models. Applied Mathematical Modelling, 9(6), 441-446.

Hempel, S., Frieler, K., Warszawski, L., Schewe, J., \& Piontek, F. (2013). A trend-preserving bias correction-the ISI-MIP approach. Earth System Dynamics, 4(2), 219-236.

Hipsey, M. R., Bruce, L. C., Boon, C., Busch, B., Carey, C., C Hamilton, D. P., Hanson, P. C.,

Read, J. S., de Sousa, E., Weber, M., Winslow, L. A. (2019). A General Lake Model (GLM 3.0) for linking with high-frequency sensor data from the Global Lake Ecological Observatory Network (GLEON). Geoscientific Model Development,12,473-523.

Hostetler, S. W. (1991). Simulation of lake ice and its effect on the late-Pleistocene evaporation rate of Lake Lahontan. Climate Dynamics, 6(1), 43-48.

Hostetler, S. W., \& Bartlein, P. J. (1990). Simulation of lake evaporation with application to modeling lake level variations of Harney-Malheur Lake, Oregon. Water Resources Research, 26(10), 2603-2612.

Ito, A., Reyer, C., Gaedeke, A., Ciais, P., Chang, J., Chen, M., Francois, L., Forrest, M., Hickler, T., Ostberg, S., Hao, S. Thiery, W., Tian, H., Pronounced and unavoidable impacts of low-end 
global warming on northern high-latitude land ecosystems, Environmental Research Letters, 15, 044006.

Jane, S., Hansen, G.J.A., Kraemer, B.M., Leavitt, P.R., North, R.L., Pilla, R.M., Williamson, C.E.,

Woolway, R.I., Arvola, L., Chandra, S., DeGasperi, C., Diemer, L., Dunalska, J., Erina, O., Flaim, G., Grossart, H.-P., Hambright, K.D., Hein, C., Hejzlar, J., Janus, L., Jenny, J.-P., Jones, J., Knoll, L.B., Leoni, B., MacKay, E., Matsuzaki, S.-I., McBride, C., Müller-Navarra, D.C., Paterson, A.M., Pierson, D., Rogora, M., Rusak, J., Sadro, S., Saulnier-Talbot, E., Schmid, M., Sommaruga, R., Thiery, W., Weyhenmeyer, G., Yokota, K., Rose, K.C., 2021 Widespread deoxygenation of temperate lakes, Nature, 594, 66-70.

Janssen, A. B. G., et al. (2019). "How to model algal blooms in any lake on earth." Current Opinion in Environmental Sustainability 36: 1-10.

Jenny J.-P., Anneville O., Arnaud F., Baulaz Y., Bouffard D., Domaizon I., Bocaniov S. A., Chèvre N., Dittrich M., Dorioz J.-M., Dunlop E. S., Dur G., Guillard J., Guinaldo T., Jacquet S., Jamoneau A., Jawed Z., Jeppesen E., Krantzberg G., Lenters J., Leoni B., Meybeck M., Nava V., Nõges T., Nõges P., Patelli M., Pebbles V., Perga M.-E., Rasconi S., Ruetz C. R., Rudstam L., Salmaso N., Sapna S., Straile D., Tammeorg O., Twiss M. R., Uzarski D. G., Ventelä A.-M., Vincent W. F.,

Wilhelm S. W., Wängberg S.-Å., Weyhenmeyer G. A. (2020). Scientists' Warning to Humanity: Rapid degradation of the world's large lakes. Journal of Great Lakes Research, 46, 686-702. https://doi.org/10.1016/j.jglr.2020.05.006

Kraemer, B. M., Anneville, O., Chandra, S., Dix, M., Kuusisto, E., Livingstone, D. M., ... \& McIntyre, P. B. (2015). Morphometry and average temperature affect lake stratification responses to climate change. Geophysical Research Letters, 42(12), 4981-4988. 
Kraemer, B.M., Pilla, R.M., Woolway, R.I., Anneville, O., Ban, S., Colom-Montero, W., Devlin, S.P., Dokulil, M.T., Gaiser, E.E., Hambright, K.D., Hessen, D.O., Higgins, S.N., Jöhnk, K.D., Keller, W., Knoll, L.B., Leavitt, P.R., Lepori, F., Luger, M.S., Maberly, S.C., Müller-Navarra, D.C., Paterson, A.M., Pierson,, D.C., Richardson, D.C., Rogora, M., Rusak, J.A., Sadro, S., Salmaso, N.,

5 Schmid, M., Silow, E.A., Sommaruga, R., Stelzer, J.A.A., Straile, D., Thiery, W., Verburg P., Weyhenmeyer, G.A., Adrian, R. 2021, Climate change drives widespread shifts in lake thermal habitat, Nature Climate Change, 11, 521-529.

Kobler, U. G., Wüest, A., \& Schmid, M. (2019). Combined effects of pumped-storage operation and climate change on thermal structure and water quality. Climatic Change, 152(3), 413-429.

Lange, Stefan (2019a): EartH2Observe, WFDEI and ERA-Interim data Merged and Bias-corrected for ISIMIP (EWEMBI). V. 1.1. GFZ Data Services. https://doi.org/10.5880/pik.2019.004

Lange, S. (2019b). Trend-preserving bias adjustment and statistical downscaling with ISIMIP3BASD (v1. 0). Geoscientific Model Development, 12(7), 3055-3070.

Lange, S., Volkholz, J., Geiger, T., Zhao, F., Vega, I., Veldkamp, T., Reyer, C.P.O., Warszawski, L., Huber, V., Jägermeyr, J., Schewe, J., Bresch, D.N., Büchner, M., Chang, J., Ciais, J., Dury, M., Emanuel, K., Folberth, C., Gerten, D., Gosling, S.N., Grillakis, M., Hanasaki, N., Henrot, A.-J., Hickler, T., Honda, Y., Ito, A., Khabarov, N., Koutroulis, A., Liu, W., Müller, C., Nishina, K., Ostberg, S., Müller Schmied, H., Seneviratne, S.I., Stacke, T., Steinkamp, J., Thiery, W., Wada, Y., Willner, S., Yang, H., Yoshikawa, M., Yue, C., Frieler, K. (2020) Projecting exposure to extreme climate impact events across six event categories and three spatial scales, Earth's Future, 8(12). 
Lawrence, D. M., Oleson, K. W., Flanner, M. G., Thornton, P. E., Swenson, S. C., Lawrence, P. J., ... \& Slater, A. G. (2011). Parameterization improvements and functional and structural advances in version 4 of the Community Land Model. Journal of Advances in Modeling Earth Systems, 3(1).

Lehner, B., \& Döll, P. (2004). Development and validation of a global database of lakes, reservoirs and wetlands. Journal of Hydrology, 296(1-4), 1-22.

Lehner, B., Liermann, C.R., Revenga, C., Vörösmarty, C., Fekete, B., Crouzet, P., Döll, P., Endejan, M., Frenken, K., Magome, J., Nilsson, C., Robertson, J.C., Rödel, R., Sindorf, N. and Wisser, D. 10 (2011), High-resolution mapping of the world's reservoirs and dams for sustainable river-flow management. Frontiers in Ecology and the Environment, 9(9), 494-502.

Magee, M. R., Wu, C. H., Robertson, D. M., Lathrop, R. C., \& Hamilton, D. P. (2016). Trends and abrupt changes in 104 years of ice cover and water temperature in a dimictic lake in response to air temperature, wind speed, and water clarity drivers. Hydrology and Earth System Sciences, 20(5), 1681-1702.

Magee, M. R., Hein, C. L., Walsh, J. R., Shannon, P. D., Vander Zanden, M. J., Campbell, T. B., ... \& Janowiak, M. K. (2019). Scientific advances and adaptation strategies for Wisconsin lakes facing climate change. Lake and Reservoir Management, 35(4), 364-381.

Marcé, R., George, G., Buscarinu, P., Deidda, M., Dunalska, J., de Eyto, E., ... \& Jennings, E. (2016). Automatic high frequency monitoring for improved lake and reservoir management. Environmental Science \& Technology, 50(20), 10780-10794.

Masson-Delmotte, V., Zhai, P., Pörtner, H. O., Roberts, D., Skea, J., Shukla, P. R., ... \& Waterfield, T. (2018). Global warming of 1.5 C. An IPCC Special Report on the impacts of global warming of 
$1.5^{\circ} \mathrm{C}$ above pre-industrial levels and related global greenhouse gas emission pathways, in the context of strengthening the global response to the threat of climate change, sustainable development, and efforts to eradicate poverty.

5 Mengel, M., Treu, S., Lange, S., \& Frieler, K. (2021). ATTRICI v1. 1-counterfactual climate for impact attribution. Geoscientific Model Development, 14(8), 5269-5284.

Mesman, J. P., Ayala, A. I., Adrian, R., De Eyto, E., Frassl, M. A., Goyette, S., ... \& Ibelings, B. W. (2020). Performance of one-dimensional hydrodynamic lake models during short-term extreme weather events. Environmental Modelling \& Software, 133, 104852.

Messager, M. L., Lehner, B., Grill, G., Nedeva, I., \& Schmitt, O. (2016). Estimating the volume and age of water stored in global lakes using a geo-statistical approach. Nature communications, $7(1), 1-11$.

Mironov, D. V. (2008). Parameterization of Lakes in Numerical Weather Prediction. Description of a Lake Model. COSMO Technical Report, 11, 47.

Moras, S., Ayala, A. I., \& Pierson, D. C. (2019). Historical modelling of changes in Lake Erken thermal conditions. Hydrology and Earth System Sciences, 23(12), 5001-5016.

Oleson, K. W., et al. et al. (2013). Technical description of version 4.5 of the Community Land Model (CLM)Tech. Rep., Natl. Center for Atmos. Res, None,420.

O'Reilly, C. M., Sharma, S., Gray, D. K., Hampton, S. E., Read, J. S., Rowley, R. J., ... \& Zhang, G. (2015). Rapid and highly variable warming of lake surface waters around the globe. Geophysical Research Letters, 42(24), 10-773. 
Patterson, J. C., \& Hamblin, P. F. (1988). Thermal simulation of a lake with winter ice cover 1. Limnology and Oceanography, 33(3), 323-338.

Perroud, M., Goyette S., Martynov A., Beniston M. \& Anneville O. (2009). Simulation of multiannuel thermal profiles in deep Lake Geneva: A comparison of one-dimensional lake models. Limnology and Oceanograpy, 54(5), $1574-1594$.

Piccolroaz, S., Toffolon, M., \& Majone, B. (2013). A simple lumped model to convert air temperature into surface water temperature in lakes. Hydrology and earth system sciences, 17(8), 3323-3338.

Piccolroaz, S. (2016). Prediction of lake surface temperature using the air2water model: guidelines, challenges, and future perspectives. Advances in Oceanography and Limnology, 7(1), 36-50.

Piccolroaz, S., Healey, N.C., Lenters, J.D., Schladow, S.G., Hook, S.J., Sahoo, G.B. and Toffolon, M. (2018). On the predictability of lake surface temperature using air temperature in a changing climate: A case study for Lake Tahoe (U.S.A.). Limnology and Oceanography, 63, 243-261.

Piccolroaz, S., Woolway, R. I., \& Merchant, C. J. (2020). Global reconstruction of twentieth century lake surface water temperature reveals different warming trends depending on the climatic zone. Climatic Change, 160(3), 427-442.

Pilla, R.M., Williamson, C.E., Adamovich, B.V., Adrian, R., Anneville, O., Chandra, S., ColomMontero, W., Devlin, S.P., Dix, M.A., Dokulil, M.T., Gaiser, E.E., Girdner, S.F., Hambright, K.D., Hamilton, D.P., Havens, K., Hessen, D.O., Higgins, S.N., Huttula, T.H., Huuskonen, H., Isles, P.D.F., Joehnk, K.D., Jones, I.D., Keller, W.B., Knoll, L.B., Korhonen, J., Kraemer, B.M., Leavitt, 
P.R., Lepori, F., Luger, M.S., Maberly, S.C., Melack, J.M., Melles, S.J., Müller-Navarra, D.C., Pierson, D.C., Pislegina, H.V., Plisnier, P.-D., Richardson, D.C., Rimmer, A., Rogora, M., Rusak, J.A., Sadro, S., Salmaso, N., Saros, J.E., Saulnier-Talbot, E., Schindler, D.E., Schmid, M., Shimaraeva, S.V., Silow, E.A., Sitoki, L.M., Sommaruga, R., Straile, D., Strock, K.E., Thiery, W.,

5 Timofeyev, M.A., Verburg, P., Vinebrooke, R.D., Weyhenmeyer, G.A., Zadereev, E., 2020, Deep waters are warming less consistently than surface waters in a global analysis of 102 lakes, Scientific Reports, 10, 20514.

Pilla, R. M., Mette, E. M., Williamson, C. E., Adamovich, B. V., Adrian, R., Anneville, O., ... \&

Zhukova, T. V. (2021). Global data set of long-term summertime vertical temperature profiles in 153 lakes. Scientific data, 8(1), 1-12.

Prats, J., \& Danis, P. A. (2019). An epilimnion and hypolimnion temperature model based on air temperature and lake characteristics. Knowledge \& Management of Aquatic Ecosystems, (420), 8.

Pokhrel, Y., Felfelani, F., Satoh, Y., Boulange, J., Burek, P., Gädeke, A., Gerten, D., Gosling, S. N., Grillakis, M., Gudmundsson, L., Hanasaki, N., Kim, H., Koutroulis, A., Liu, J., Papadimitriou, L., Schewe, J., Müller Schmied, H., Stacke, T., Telteu, C. E., Thiery, W., Veldkamp, T., Zhao, F., Wada, Y., Global Terrestrial Water Storage and Drought Severity under Climate Change, Nature

Climate Change, 11, 226-233.

Potes, M., Costa, M. J., \& Salgado, R. (2012). Satellite remote sensing of water turbidity in Alqueva reservoir and implications on lake modelling. Hydrology and Earth System Sciences, 16(6), 16231633.

Reinecke, R., Müller Schmied, H., Trautmann, T., Burek, P., Flörke, M., Gosling, S.N., Grillakis, M., Hanasaki, N., Koutroulis, A., Pokhrel, Y., Seaby, L., Thiery, W., Wada, Y., Yusuke, S., Döll, 
P., Uncertainty of simulated groundwater recharge at different global warming levels: A globalscale multi-model ensemble study, Hydrology and Earth System Sciences, 25, 787-810.

Rimet, F., Anneville, O., Barbet, D., Chardon, C., Crepin, L., Domaizon, I., ... \& Monet, G. (2020).

5 The Observatory on LAkes (OLA) database: Sixty years of environmental data accessible to the public. Journal of Limnology, 79(2), 164-178.

Sachse, R., Petzoldt, T., Blumstock, M., Moreira, S., Pätzig, M., Rücker, J., ... \& Hilt, S. (2014). Extending one-dimensional models for deep lakes to simulate the impact of submerged macrophytes on water quality. Environmental Modelling \& Software, 61, 410-423.

Saloranta, T. M., \& Andersen, T. (2007). MyLake-A multi-year lake simulation model code suitable for uncertainty and sensitivity analysis simulations. Ecological Modelling, 207(1), 45-60.

15 Schewe, J., Gosling, S. N., Reyer, C., Zhao, F., Ciais, P., Elliott, J., ... \& Warszawski, L. (2019). State-of-the-art global models underestimate impacts from climate extremes. Nature communications, 10(1), 1-14.

Schleussner, C.-F., Deryng, D., Müller, C., Elliott, J., Folberth, C., Liu, W., Wang, X., Pugh, T.,

20 Thiery, W., Seneviratne, S., Rogelj, J., Crop productivity changes at $1.5^{\circ} \mathrm{C}$ and $2^{\circ} \mathrm{C}$ under climate response uncertainty, Environmental Research Letters, 13(6), 064007.

Schwefel, R., Gaudard, A., Wüest, A., \& Bouffard, D. (2016). Effects of climate change on deepwater oxygen and winter mixing in a deep lake ( $\mathrm{L}$ ake $\mathrm{G}$ eneva): Comparing observational findings and modeling. Water Resources Research, 52(11), 8811-8826. 
Settele, J., Scholes, R., Betts, R. A., Bunn, S., Leadley, P., Nepstad, D., ... \& Winter, M. (2015). Terrestrial and inland water systems. In Climate change 2014 impacts, adaptation and vulnerability: Part A: Global and sectoral aspects (pp. 271-360). Cambridge University Press.

5 Sharma, S., Blagrave, K., Magnuson, J. J., O’Reilly, C. M., Oliver, S., Batt, R. D., ... \& Woolway, R. I. (2019). Widespread loss of lake ice around the Northern Hemisphere in a warming world. Nature Climate Change, 9(3), 227-231.

Shatwell, T., Thiery, W., Kirillin, G., 2019, Future projections of temperature and mixing regime of European temperate lakes, Hydrology and Earth System Sciences, 23, 1533-1551.

Spence, C., Blanken, P. D., Lenters, J. D., \& Hedstrom, N. (2013). The importance of spring and autumn atmospheric conditions for the evaporation regime of Lake Superior. Journal of Hydrometeorology, 14(5), 1647-1658.

Stepanenko, V. M., Goyette, S., Martynov, A., Perroud, M., Fang, X., \& Mironov, D. (2010). First steps of a lake model intercomparison project: LakeMIP, Boreal Environmental Research, 15, 191202.

Stepanenko, V. M., Martynov, A., Jöhnk, K. D., Subin, Z. M., Perroud, M., Fang, X., ... \& Goyette, S. (2013). A one-dimensional model intercomparison study of thermal regime of a shallow, turbid midlatitude lake. Geoscientific Model Development, 6(4), 1337-1352.

Stepanenko V, Mammarella I, Ojala A, Miettinen H, Lykosov V, Vesala T et al. LAKE 2.0: a model Development,9,1977-2006,2016 
Subin, Z. M., Riley, W. J., \& Mironov, D. (2012). An improved lake model for climate simulations: Model structure, evaluation, and sensitivity analyses in CESM1. Journal of Advances in Modeling Earth Systems, 4(1).

5 Tan, Z., Zhuang, Q., \& Walter Anthony, K. (2015). Modeling methane emissions from arctic lakes: Model development and site-level study. Journal of Advances in Modeling Earth Systems, 7(2), 459-483.

Tan, Z., Zhuang, Q., Shurpali, N. J., Marushchak, M. E., Biasi, C., Eugster, W., \& Walter Anthony, 10 K. (2017). Modeling CO2 emissions from Arctic lakes: Model development and site-level study. Journal of Advances in Modeling Earth Systems, 9, 2190-2213.

Tan, Z., Yao, H., \& Zhuang, Q. (2018). A small temperate lake in the 21st century: dynamics of water temperature, ice phenology, dissolved oxygen, and chlorophyll a. Water Resources Research, 54(7), 4681-4699.

Taylor, K. E., Stouffer, R. J., \& Meehl, G. A. (2012). An overview of CMIP5 and the experiment design. Bulletin of the American Meteorological Society, 93(4), 485-498.

Thiery, W. I. M., Stepanenko, V. M., Fang, X., Jöhnk, K. D., Li, Z., Martynov, A., ... \& Van Lipzig, N. P. (2014). LakeMIP Kivu: evaluating the representation of a large, deep tropical lake by a set of one-dimensional lake models. Tellus A: Dynamic Meteorology and Oceanography, 66(1), 21390.

Thiery, W., Davin, E. L., Panitz, H. J., Demuzere, M., Lhermitte, S., \& Van Lipzig, N. (2015). The impact of the African Great Lakes on the regional climate. Journal of Climate, 28(10), 4061-4085. 
Thiery, W., Davin, E. L., Seneviratne, S. I., Bedka, K., Lhermitte, S., \& Van Lipzig, N. P. (2016). Hazardous thunderstorm intensification over Lake Victoria. Nature communications, 7(1), 1-7.

Thiery, W., Lange, S., Rogelj, J., Schleussner, C.-F., Gudmundsson, L., Seneviratne, S.I., Frieler, K., Emanuel, K., Geiger, T., Bresch, D.N., Zhao, F., Willner, S.N., Büchner, M., Volkholz, J., Andrijevic, M., Bauer, N., Chang, J., Ciais, P., Dury, M., François, L., Grillakis, M., Gosling, S.N., Hanasaki, N., Hickler, T., Huber, V., Ito, A., Jägermeyr, J., Khabarov, N., Koutroulis, A., Liu, W., Lutz, W., Mengel, M., Müller, C., Ostberg, S., Reyer, C.P.O., Stacke, T., Wada, Y., 2021, Intergenerational inequities in exposure to climate extremes, Science, 374(6564), 158-160.

Toffolon, M., Piccolroaz, S., Majone, B., Soja, A. M., Peeters, F., Schmid, M., \& Wüest, A. (2014). Prediction of surface temperature in lakes with different morphology using air temperature. Limnology and Oceanography, 59(6), 2185-2202.

15 Toptunova, O., Choulga, M., \& Kurzeneva, E. (2019). Status and progress in global lake database developments. Advances in Science and Research, 16, 57-61.

Trolle, D., Elliott, J. A., Mooij, W. M., Janse, J. H., Bolding, K., Hamilton, D. P., \& Jeppesen, E. (2014). Advancing projections of phytoplankton responses to climate change through ensemble modelling. Environmental Modelling \& Software, 61, 371-379.

Umlauf, L., \& Lemmin, U. (2005). Interbasin exchange and mixing in the hypolimnion of a large lake: The role of long internal waves. Limnology and Oceanography, 50(5), 1601-1611.

Vanderkelen I., van Lipzig N.P.M., Lawrence D. M., Droppers B., Gosling S. N., Janssen A. B. G., Marcé R., Müller-Schmied H., Perroud M., Pierson D., Pokhrel Y., Satoh Y., Schewe J., 
Seneviratne S. I., Stepanenko V. M., Tan Z., Woolway R. I., Thiery W. (2020) Global heat uptake by inland waters. Geographical Research Letters. 47(12), e2020GL087867.

Vanderkelen I., van Lipzig N. P. M., Sacks W. J., Lawrence D. M., Clark M., Mizukami N., Pokhrel 5 Y., Thiery W. (2021). Simulating the Impact of Global Reservoir Expansion on the Present-Day Climate. Journal of Geophysical Research: Atmospheres, 126(16), e2020JD034485.

Verpoorter, C., Kutser, T., Seekell, D. A., \& Tranvik, L. J. (2014). A global inventory of lakes based on high-resolution satellite imagery. Geophysical Research Letters, 41(18), 6396-6402.

Weathers, K.C., Hanson, P.C., Arzberger, P., Brentrup, J., Brookes, J., Carey, C.C., Gaiser, E., Gaiser, E., Hamilton, D.P., Hong, G.S., Ibelings, B., Istvánovics, V., Jennings, E., Kim, B., Kratz, T., Lin, F.-P., Muraoka, K., O'Reilly, C., Rose, K.C., Ryder, E. and Zhu, G. (2013), The Global Lake Ecological Observatory Network (GLEON): the evolution of grassroots network science,

Limnology and Oceanography Bulletin, 22: 71-73.

Woolway, R. I., \& Merchant, C. J. (2019). Worldwide alteration of lake mixing regimes in response to climate change. Nature Geoscience, 12(4), 271-276.

Woolway, R. I., Weyhenmeyer, G. A., Schmid, M., Dokulil, M. T., de Eyto, E., Maberly, S. C., ... \& Merchant, C. J. (2019). Substantial increase in minimum lake surface temperatures under climate change. Climatic Change, 155(1), 81-94.

Woolway, R. I., Kraemer, B. M., Lenters, J. D., Merchant, C. J., O’Reilly, C. M., \& Sharma, S. (2020). Global lake responses to climate change. Nature Reviews Earth \& Environment, 1(8), 388403. 
Woolway, R. I., Jennings, E., Shatwell, T., Golub, M., Pierson, D. C., \& Maberly, S. C. (2021). Lake heatwaves under climate change. Nature, 589(7842), 402-407.

Woolway, R. I., Sharma, S., Weyhenmeyer, G. A., Debolskiy, A., Golub, M., Mercado-Bettín, D., 5 ... \& Jennings, E. (2021). Phenological shifts in lake stratification under climate change. Nature communications, 12(1), 1-11.

Weyhenmeyer, G. A., Livingstone, D. M., Meili, M., Jensen, O., Benson, B., \& Magnuson, J. J. (2011). Large geographical differences in the sensitivity of ice-covered lakes and rivers in the 10 Northern Hemisphere to temperature changes. Global Change Biology, 17(1), 268-275. 


\section{Tables}

Table 1. Overview on lake impact models participating in the Lake Sector of ISIMIP2a/b.

\begin{tabular}{|c|c|c|c|c|c|c|c|c|c|}
\hline $\begin{array}{l}\text { Lake model } \\
\text { and version }\end{array}$ & \begin{tabular}{|l|} 
Brief model \\
description \\
Defining features \\
and key processes
\end{tabular} & $\begin{array}{l}\text { Spatial } \\
\text { domain }\end{array}$ & $\begin{array}{l}\text { Timestep } \\
\text { Simulated } \\
/ \\
\text { Reported } \\
\text { [Hours] }\end{array}$ & \begin{tabular}{|l} 
Vertical \\
structure / \\
layers \\
reported
\end{tabular} & $\begin{array}{l}\text { Parameterizatio } \\
\text { n of turbulent } \\
\text { fluxes at air- } \\
\text { water interface }\end{array}$ & $\begin{array}{l}\text { Turbulent } \\
\text { mixing } \\
\text { parameterisatio } \\
\text { n }\end{array}$ & $\begin{array}{l}\text { Water-sediment } \\
\text { interface } \\
\text { parameterisatio } \\
\text { n }\end{array}$ & $\begin{array}{l}\text { Ice } \\
\text { module }\end{array}$ & $\begin{array}{l}\text { Key } \\
\text { references }\end{array}$ \\
\hline $\begin{array}{l}\text { air2water4pa } \\
\text { r } \\
\text { (ver. 2.0.0) }\end{array}$ & $\begin{array}{l}\text { A hybrid physically- } \\
\text { based/statistical } \\
\text { model to predict } \\
\text { Lake Surface Water } \\
\text { Temperature } \\
\text { (LSWT) and } \\
\text { epilimnion thickness } \\
\text { relying solely on air } \\
\text { temperature as } \\
\text { external forcing. } \\
\end{array}$ & $L$ & $24 / 24$ & $\begin{array}{l}\text { Single layer / } \\
1\end{array}$ & $\begin{array}{l}\text { From simplified } \\
\text { version of the net } \\
\text { heat flux }\end{array}$ & $\begin{array}{l}\text { Bulk semi- } \\
\text { empirical } \\
\text { relations that can } \\
\text { be derived from } \\
\text { turbulence theory } \\
\text { of Henderson- } \\
\text { Sellers }\end{array}$ & N & $\mathrm{N}$ & $\begin{array}{l}\text { Piccolraz et al. } \\
(2013) \\
\text { Piccolroaz } \\
(2016)\end{array}$ \\
\hline $\begin{array}{l}\text { air2water6pa } \\
\text { r } \\
\text { (ver. 2.0.0) }\end{array}$ & $\begin{array}{l}\text { As above but with } \\
\text { six parameters }\end{array}$ & $L$ & $24 / 24$ & $\begin{array}{l}\text { Single layer / } \\
1\end{array}$ & Same as above & Same as above & $\mathrm{N}$ & $\mathrm{N}$ & $\begin{array}{l}\text { Piccolroaz et } \\
\text { al. (2013) } \\
\\
\text { Piccolroaz } \\
(2016)\end{array}$ \\
\hline $\begin{array}{l}\text { ALBM } \\
\text { (ver. 2.0) }\end{array}$ & $\begin{array}{l}\text { One-dimensional } \\
\text { process-based lake } \\
\text { biogeochemistry } \\
\text { model that can } \\
\text { simulate the } \\
\text { dynamics of water } \\
\text { temperature, ice } \\
\text { phenology, dissolved } \\
\text { oxygen, } \\
\text { phytoplankton and } \\
\text { carbon } \\
\end{array}$ & L/G & $24 / 24$ & Multilayer / 51 & $\begin{array}{l}\text { Calculated } \\
\text { following the } \\
\text { method of } \\
\text { Koehler et al. } \\
(2014)\end{array}$ & $\begin{array}{l}\text { Henderson- } \\
\text { Sellers thermal } \\
\text { diffusion model } \\
\text { with wind-driven } \\
\text { eddy diffusivity }\end{array}$ & $Y$ & $Y$ & $\begin{array}{l}\text { Tan et al. } \\
(2015)\end{array}$ \\
\hline $\begin{array}{l}\text { CLM } \\
\text { (ver. 4.5) }\end{array}$ & $3 D$ & $G$ & $6 / 24$ & Multilayer / 10 & $\begin{array}{l}\text { Calculated as } \\
\text { the harmonic } \\
\text { mean of the } \\
\text { conductivities of } \\
\text { the neighboring } \\
\text { layers }\end{array}$ & $\begin{array}{l}\text { Hendenson- } \\
\text { Sellers thermal } \\
\text { diffusion model } \\
\text { with wind driven } \\
\text { diffusivity }\end{array}$ & Y & $Y$ & $\begin{array}{l}\text { Subin et al., } \\
(2012) \\
\text { Oleson et al., } \\
(2013)\end{array}$ \\
\hline $\begin{array}{l}\text { Flake-IGB } \\
\text { (ver. 1.0) }\end{array}$ & \begin{tabular}{|l|} 
One-dimensional \\
bulk model of the \\
lake thermal regime \\
specifically designed \\
to parameterize \\
inland waters in \\
climate models and \\
numerical weather \\
prediction systems.
\end{tabular} & L & $3 / 24$ & $\begin{array}{l}\text { Two-layer self- } \\
\text { similar } \\
\text { structure / } 4\end{array}$ & $\begin{array}{l}\text { The Monin- } \\
\text { Obukhov } \\
\text { similarity } \\
\text { relations }\end{array}$ & \begin{tabular}{|l|} 
The water \\
surface \\
temperature is \\
equal to the \\
mixed-layer \\
temperature, this \\
is computed from \\
calculation and \\
constant update \\
of heat fluxes \\
\end{tabular} & N & $\mathrm{Y}$ & $\begin{array}{l}\text { Mironov et al. } \\
2008\end{array}$ \\
\hline $\begin{array}{l}\text { GLM } \\
\text { (ver. 3.0.0) }\end{array}$ & $\begin{array}{l}\text { A one-dimensional } \\
\text { open source } \\
\text { hydrodynamic } \\
\text { model. It simulates } \\
\text { temperature }\end{array}$ & $L$ & $24 / 24$ & $\begin{array}{l}\text { Multilayer/ } \\
0.5 \mathrm{~m} \text { - } \\
\text { max.depth }\end{array}$ & $\begin{array}{l}\text { Algorithm used } \\
\text { in Imberger and } \\
\text { Patterson } \\
(1981)\end{array}$ & $\begin{array}{l}\text { Energy balance } \\
\text { approach for } \\
\text { surface layer } \\
\text { mixing, eddy } \\
\text { diffusivity }\end{array}$ & $N$ & $\mathrm{~N}$ & $\begin{array}{l}\text { Hipsey et al. } \\
(2019)\end{array}$ \\
\hline
\end{tabular}




\begin{tabular}{|c|c|c|c|c|c|c|c|c|c|}
\hline & \begin{tabular}{|l|} 
stratification in lakes. \\
It uses a flexible \\
Lagrangian grid and \\
an energy budget \\
approach for mixing. \\
\end{tabular} & & & & & $\begin{array}{l}\text { approach for } \\
\text { deep mixing }\end{array}$ & & & \\
\hline $\begin{array}{l}\text { GOTM } \\
\text { (ver. 5.1) }\end{array}$ & \begin{tabular}{|l|} 
A one-dimensional \\
water column model \\
for the most \\
important \\
hydrodynamic and \\
thermodynamic \\
processes related to \\
vertical mixing in \\
natural waters. \\
\end{tabular} & $\mathrm{L}$ & $24 / 24$ & $\begin{array}{l}\text { Multiple/ } 0.5 \mathrm{~m} \\
\text { - max.depth }\end{array}$ & $\begin{array}{l}\text { Based on Fairall } \\
\text { et. al. (1996) }\end{array}$ & $k-\varepsilon$ model & N & $N$ & $\begin{array}{l}\text { Umlauf et al., } \\
(2005) ; \\
\text { Burhard et al., } \\
(2006) ;\end{array}$ \\
\hline $\begin{array}{l}\text { GOTM } \\
\text { (ver. 5.3) }\end{array}$ & As above & G & $24 / 24$ & Multilayer / 10 & $\begin{array}{l}\text { Based on Fairall } \\
\text { et. al. (1996) }\end{array}$ & $k-\varepsilon$ model & $N$ & $Y$ & $\begin{array}{l}\text { Umlauf et al., } \\
\text { (2005); Burhar } \\
\text { d et al., } \\
(2006) ;\end{array}$ \\
\hline $\begin{array}{l}\text { LAKE } \\
(\text { ver. 2.0) }\end{array}$ & $\begin{array}{l}\text { 1D model for lake } \\
\text { thermohydrodynamic } \\
\text { s and } \\
\text { biogeochemistry }\end{array}$ & G & $24 / 24$ & Multilayer/ 20 & $\begin{array}{l}\text { Based on } \\
\text { Monin-Obukhov } \\
\text { similarity theory }\end{array}$ & $\begin{array}{l}\text { k- } \varepsilon \text { model / } \\
\text { Henderson- } \\
\text { Sellers thermal } \\
\text { diffusion model }\end{array}$ & Y & $Y$ & $\begin{array}{l}\text { Stepanenko et } \\
\text { al., (2016) }\end{array}$ \\
\hline $\begin{array}{l}\text { MyLake } \\
\text { (ver. 1.12) }\end{array}$ & $\begin{array}{l}\text { One-dimensional } \\
\text { lake model w ice } \\
\text { module. }\end{array}$ & $\mathrm{L}$ & $24 / 24$ & $\begin{array}{l}\text { Multilayer/0.5 } \\
\text { m - max.depth }\end{array}$ & \begin{tabular}{|l} 
Difussion \\
coefficient in \\
heat balance
\end{tabular} & $\begin{array}{l}\text { Hondzo and } \\
\text { Stefan } \\
\text { thermal diffusion } \\
\text { model }\end{array}$ & Y & $Y$ & $\begin{array}{l}\text { Saloranta \& } \\
\text { Andersen } \\
(2007)\end{array}$ \\
\hline $\begin{array}{l}\text { Simstrat } \\
\text { (ver. 2.1.2) }\end{array}$ & $\begin{array}{l}\text { One dimensional } \\
\text { lake model with } \\
\text { deep seiche mixing, } \\
\text { ice- and river } \\
\text { intrusion module } \\
\end{array}$ & $\mathrm{L}$ & $24 / 24$ & $\begin{array}{l}\text { Multilayer/ } \\
0.5 \mathrm{~m} \text { - max } \\
\text { depth }\end{array}$ & $\begin{array}{l}\text { Dirichlet } \\
\text { condition }\end{array}$ & $\begin{array}{l}\mathrm{k}-\varepsilon \text { turbulence } \\
\text { model with } \\
\text { buoyancy and } \\
\text { internal seiche } \\
\text { parameterization }\end{array}$ & N & Y & $\begin{array}{l}\text { Goudsmit et } \\
\text { al., (2002) }\end{array}$ \\
\hline $\begin{array}{l}\text { Simstrat- } \\
\text { UoG } \\
\text { (ver. 1.0.0) }\end{array}$ & As above & G & $3 / 24$ & $\begin{array}{l}\text { Multilayer/ 1- } \\
13\end{array}$ & $\begin{array}{l}\text { Dirichlet } \\
\text { condition }\end{array}$ & 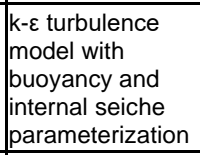 & $N$ & $Y$ & $\begin{array}{l}\text { Goudsmit et } \\
\text { al., (2002) }\end{array}$ \\
\hline $\begin{array}{l}\text { VIC-Lake } \\
\text { (ver. 1.0) }\end{array}$ & $\begin{array}{l}\text { One dimensional } \\
\text { lake lake model } \\
\text { derived from the } \\
\text { Variable Infiltration } \\
\text { Capacity (VIC) } \\
\text { Macroscale } \\
\text { Hydrologic Model. }\end{array}$ & G & $6 / 24$ & $\begin{array}{l}\text { Multilayer / } \\
1000\end{array}$ & $\begin{array}{l}\text { Based } \\
\text { on Hostetler and } \\
\text { Bartlein (1990) }\end{array}$ & $\begin{array}{l}\text { Henderson- } \\
\text { Sellers thermal } \\
\text { diffusion model } \\
\text { with } \\
\text { parameterized } \\
\text { eddy diffusivity }\end{array}$ & N & $Y$ & \begin{tabular}{|l} 
Bowling \\
$\&$ Lettenmaier \\
$(2010)$
\end{tabular} \\
\hline
\end{tabular}

${ }^{(1)}$ Spatial scale of simulated impacts: L - Local (site-specific); G-Global 
Table 2. Standard climate forcing variables used to govern lake models to simulate past, present, future changes in local and global lakes

\begin{tabular}{|c|c|c|c|c|c|c|c|c|c|c|c|c|c|c|}
\hline$\frac{\frac{0}{2}}{\frac{\pi}{\frac{\pi}{\pi}}}$ & $\begin{array}{l}\frac{\overline{0}}{\overline{0}} \\
\frac{0}{0} \\
\frac{0}{0} \\
\frac{0}{0}\end{array}$ & 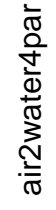 & 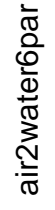 & 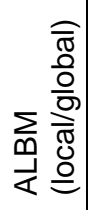 & $\sum_{0}^{\infty}$ & 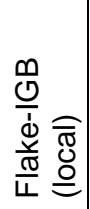 & $\sum_{\substack{0 \\
0}}^{\infty}$ & 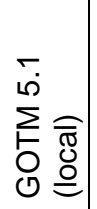 & 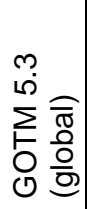 & 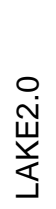 & 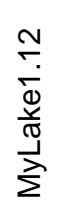 & 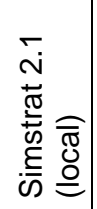 & 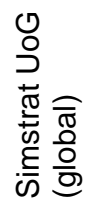 & 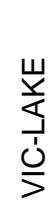 \\
\hline $\begin{array}{l}\text { Near-surface relative } \\
\text { humidity [\%] }\end{array}$ & hurs & & & $\bullet$ & & & • & & & & • & & & $\bullet$ \\
\hline $\begin{array}{l}\text { Near-surface specific } \\
\text { humidity }\left[\mathrm{kg} \mathrm{kg}^{-1}\right]\end{array}$ & huss & & & & • & • & & • & • & $\bullet$ & & $\bullet$ & $\bullet$ & \\
\hline $\begin{array}{l}\text { Precipitation } \\
{\left[\mathrm{kg} \mathrm{m}^{-2} \mathrm{~s}^{-1}\right]}\end{array}$ & $\mathrm{pr}$ & & & $\bullet$ & $\bullet$ & & $\bullet$ & $\bullet$ & $\bullet$ & $\bullet$ & $\bullet$ & $\bullet$ & $\bullet$ & $\bullet$ \\
\hline $\begin{array}{l}\text { Snowfall flux } \\
{\left[\mathrm{kg} \mathrm{m}^{-2} \mathrm{~s}^{-1}\right]}\end{array}$ & prsn & & & $\bullet$ & & & & & & & & & & \\
\hline Surface pressure $[\mathrm{Pa}]$ & ps & & & $\bullet$ & & & & $\bullet$ & $\bullet$ & $\bullet$ & $\bullet$ & $\bullet$ & $\bullet$ & $\bullet$ \\
\hline $\begin{array}{l}\text { Surface downwelling } \\
\text { longwave radiation } \\
{\left[\mathrm{W} \mathrm{m}^{-2}\right]}\end{array}$ & rlds & & & $\bullet$ & • & • & $\bullet$ & & & $\bullet$ & & $\bullet$ & $\bullet$ & $\bullet$ \\
\hline $\begin{array}{l}\text { Surface downwelling } \\
\text { shortwave radiation } \\
{\left[\mathrm{W} \mathrm{m}^{-2}\right]}\end{array}$ & rsds & & & • & • & • & • & • & $\bullet$ & • & $\bullet$ & • & $\bullet$ & • \\
\hline $\begin{array}{l}\text { Near-surface wind } \\
\text { speed at } 10 \mathrm{~m}\left[\mathrm{~m} \mathrm{~s}^{-1}\right]\end{array}$ & $\begin{array}{l}\text { sfcWin } \\
\text { d }\end{array}$ & & & $\bullet$ & $\bullet$ & $\bullet$ & $\bullet$ & $\bullet$ & $\bullet$ & $\bullet$ & $\bullet$ & $\bullet$ & $\bullet$ & $\bullet$ \\
\hline $\begin{array}{l}\text { Near-surface air } \\
\text { temperature } \\
{[\mathrm{K}]}\end{array}$ & tas & $\bullet$ & $\bullet$ & $\bullet$ & $\bullet$ & $\bullet$ & $\bullet$ & & & $\bullet$ & $\bullet$ & $\bullet$ & $\bullet$ & $\bullet$ \\
\hline $\begin{array}{l}\text { Daily maximum near- } \\
\text { surface air temperature } \\
{[\mathrm{K}]}\end{array}$ & $\begin{array}{l}\text { tasma } \\
\mathrm{x}\end{array}$ & & & $\bullet$ & & $(\bullet)$ & & & & & & & & \\
\hline $\begin{array}{l}\text { Daily minimum near- } \\
\text { surface air temperature } \\
{[\mathrm{K}]}\end{array}$ & tasmin & & & $\bullet$ & & $(\bullet)$ & & & & & & & & \\
\hline $\begin{array}{l}\text { Eastward near-surface } \\
\text { wind }\left[\mathrm{m} \mathrm{s}^{-1}\right]^{(1)}\end{array}$ & uas & & & & & & & $\bullet$ & & & & $\bullet$ & $\bullet$ & \\
\hline $\begin{array}{l}\text { Northward near-surface } \\
\text { wind }\left[\mathrm{m} \mathrm{s}^{-1}\right]^{(1)}\end{array}$ & vas & & & & & & & $\bullet$ & & & & $\bullet$ & $\bullet$ & \\
\hline
\end{tabular}

(1) uncorrected 
Table 3. Summary of local domain calibration of lake models participating in the ISIMIP2a/b simulation rounds. Summary statistics for calibrated parameters and models' performance represent the cross-site mean, median [minimum - maximum].

\begin{tabular}{|c|c|c|c|c|c|}
\hline \multirow{2}{*}{$\begin{array}{l}\text { Lake } \\
\text { model } \\
\text { and } \\
\text { version }\end{array}$} & \multirow[t]{2}{*}{ Calibrated parameter name } & \multirow{2}{*}{$\begin{array}{l}\text { Parameter } \\
\text { abbreviation } \\
\text { [units] }\end{array}$} & \multirow{2}{*}{$\begin{array}{l}\text { Cross-site calibrated } \\
\text { parameters summary } \\
\text { statistics }\end{array}$} & \multicolumn{2}{|c|}{ Model fit } \\
\hline & & & & RMSE & r2 \\
\hline $\begin{array}{l}\text { air2water4 } \\
\text { par } \\
\text { (ver. 2.0.0) }\end{array}$ & $\begin{array}{l}\text { 1 Fit parameter (residual effect) } \\
2 \text { Fit parameter (processes depending on air } \\
\text { temp) } \\
3 \text { Fit parameter (processes depending on } \\
\text { surface lake temp) } \\
4 \text { Scale of lake surface temperature that } \\
\text { determines the strength of the thermal } \\
\text { stratification }\end{array}$ & $\begin{array}{l}\text { a1 }\left[{ }^{\circ} \mathrm{Cd} \mathrm{d}^{-1}\right] \\
\text { a2 }\left[\mathrm{d}^{-1}\right] \\
\text { a3 }\left[\mathrm{d}^{-1}\right] \\
\text { a4 }\left[{ }^{\circ} \mathrm{C}\right]\end{array}$ & $\begin{array}{l}0.21,0.12[-0.04-2.00] \\
0.06,0.04[0.009-0.36] \\
0.06,0.05[0.009-0.40] \\
18.07,12.88[1.64-77.25]\end{array}$ & $\begin{array}{l}1.17,1.10 \\
{[0.64-2.41]}\end{array}$ & $\begin{array}{lr}0.94, & 0.97 \\
{[0.13} & - \\
0.99] & \end{array}$ \\
\hline $\begin{array}{l}\text { air2water6 } \\
\text { par } \\
\text { (ver. 2.0.0) }\end{array}$ & $\begin{array}{l}1 \text { Fit parameter (residual effect) } \\
2 \text { Fit parameter (processes depending on air } \\
\text { temp) } \\
3 \text { Fit parameter (processes depending on } \\
\text { surface lake temp) } \\
4 \text { Scale of lake surface temperature that } \\
\text { determines the strength of the thermal } \\
\text { stratification } \\
5 \text { Amplitudeof annual met forcing } \\
6 \text { Phase of annual met forcing }\end{array}$ & $\begin{array}{l}\text { a1 }\left[{ }^{\circ} \mathrm{Cd}^{-1}\right] \\
\text { a2 }\left[\mathrm{d}^{-1}\right] \\
\text { a3 }\left[\mathrm{d}^{-1}\right] \\
\text { a4 }\left[{ }^{\circ} \mathrm{C}\right] \\
\text { a5 }\left[{ }^{\circ} \mathrm{C} \mathrm{d}^{-1}\right] \\
\text { a6 }[-]\end{array}$ & $\begin{array}{l}0.42,0.24[-0.72-1.99] \\
0.047,0.03[0.005-0.18] \\
0.06,0.04[0.01-0.25] \\
15.71,11.63[2.73-77.25] \\
\\
0.29,0.16[0.02-1.81] \\
0.48,0.53[0.01-0.98]\end{array}$ & $\begin{array}{l}0.98,0.94 \\
{[0.51-1.96]}\end{array}$ & $\begin{array}{l}0.96,0.98 \\
{[0.39-0.99]}\end{array}$ \\
\hline $\begin{array}{l}\text { FLake } \\
\text { (ver. 1.0) }\end{array}$ & 1 Parameter for profile relaxation time & c_relax_C [-] & $0.357,0.234[0.001-0.9]$ & $\begin{array}{l}2.41, \quad 2.34 \\
{[1.01-4.40]}\end{array}$ & NA \\
\hline $\begin{array}{l}\text { ALBM } \\
\text { (ver. 2.0) }\end{array}$ & $\begin{array}{l}1 \text { Heat capacity of sediment } \\
2 \text { Diffuse attenuation correction factor } \\
3 \text { Heat transfer coefficient scaling factor } \\
4 \text { Sediment heat capacity } \\
5 \text { Turbulent diffusivity scaling factor } \\
6 \text { Sediment porosity } \\
7 \text { Snow density } \\
8 \text { Sediment density } \\
9 \text { Wind shielding factor }\end{array}$ & $\begin{array}{l}\operatorname{cps}\left[\mathrm{J} \mathrm{kg}^{-1} \mathrm{~K}^{-1}\right] \\
\text { feta }[-] \\
\text { hwt }[-] \\
\mathrm{ks}\left[\mathrm{W} \mathrm{m}^{-1} \mathrm{~K}^{-1}\right] \\
\text { ktscale }[-] \\
\text { por }[-] \\
\text { roun }\left[\mathrm{kg} \mathrm{m}^{-3}\right] \\
\text { rous }\left[\mathrm{kg} \mathrm{m}^{-3}\right] \\
\text { wstr }[-]\end{array}$ & $\begin{array}{l}1397,1472[770-1923] \\
1.04,0.57[0.10-6.26] \\
1.52,1.09[0.57-4.57] \\
1.25,1.04[0.26-2.82] \\
1.26,1.19[0.54-2.57] \\
0.43,0.43[0.30-0.59] \\
233,175[100-725] \\
2089,2013[1549-2662] \\
1.39,0.51[0-8.85]\end{array}$ & $\begin{array}{l}1.44,1.27 \\
{[1.27-3.07]}\end{array}$ & $\begin{array}{l}0.89,0.93 \\
{[0.10} \\
0.99]\end{array}$ \\
\hline $\begin{array}{l}\text { GLM } \\
\text { (ver. 3.0.0) }\end{array}$ & $\begin{array}{l}1 \text { Diffuse attenuation coefficient } \\
2 \text { Longwave (or cloud) scaling factor } \\
3 \text { Wind speed scaling factor }\end{array}$ & $\begin{array}{l}\mathrm{Kw}\left[\mathrm{m}^{-1}\right] \\
\mathrm{lw} \text { _factor [-] } \\
\text { wind_factor }[-]\end{array}$ & $\begin{array}{l}0.75,0.46[0.05-4.21] \\
1.01,1.02[0.77-1.33] \\
1.30,1.24[0.5-2.0]\end{array}$ & $\begin{array}{l}1.55,1.34 \\
{[0.35-4.81]}\end{array}$ & $\begin{array}{l}0.84,0.94 \\
{[0.00-0.98]}\end{array}$ \\
\hline $\begin{array}{l}\text { GOTM } \\
\text { (ver. 5.1, }\end{array}$ & $\begin{array}{l}1 \text { e-folding depth for non-visible fraction of } \\
\text { light } \\
2 \text { e-folding depth for visible fraction of light } \\
3 \text { Minimum turbulent kinetic energy } \\
4 \text { Surface heat-flux factor } \\
5 \text { Shortwave radiation factor } \\
6 \text { Wind factor } \\
\text { The automated calibration program PARSAC } \\
\text { (https://bolding- } \\
\text { bruggeman.com/portfolio/parsac/) was used) }\end{array}$ & $\begin{array}{l}\mathrm{g} 1[\mathrm{~m}] \\
\mathrm{g} 2[\mathrm{~m}] \\
\mathrm{k} \_ \text {min } \quad\left[\mathrm{m}^{2} \mathrm{~s}^{-2}\right] \\
\mathrm{x} 10^{6} \\
\text { shf_factor [-] } \\
\text { swr_factor [-] } \\
\text { wind_factor [-] }\end{array}$ & $\begin{array}{l}1.07,1.12[0.0006-3.52] \\
2.58,1.98[0-19.82] \\
1.95,0.98[0.14-10] \\
0.70,0.66[0.5-1.30] \\
1.11,1.17[0.52-1.57] \\
1.32,1.38[0.5-2.0]\end{array}$ & $\begin{array}{l}1.31,1.24 \\
{[0.26-5.17]}\end{array}$ & $\begin{array}{l}0.92,0.95 \\
{[0.09-0.99]}\end{array}$ \\
\hline $\begin{array}{l}\text { MyLake } \\
\text { (ver. 1.12) }\end{array}$ & $\begin{array}{l}1 \text { Melting ice albedo } \\
2 \text { Melting snow albedo } \\
3 \text { Wind shelter parameter } \\
4 \text { Minimum stability frequency } \\
5 \text { Non-PAR diffuse attenuation coefficient } \\
6 \text { PAR diffuse attenuation coefficient }\end{array}$ & $\begin{array}{l}\text { alb_melt_ice [-] } \\
\text { alb_melt_snow [- } \\
\text { ] } \\
\text { C_shelter }[-] \\
\mathrm{Kz} \text { N0 }\left[\mathrm{s}^{-2}\right] \times 10^{3}\end{array}$ & $\begin{array}{l}0.53,0.45[0.40-0.99] \\
0.55,0.48[0.40-0.98] \\
0.44,0.39[0.001-0.98] \\
0.41,0.43[0.014-0.99] \\
2.07,1.88[0.46-3.90] \\
0.95,0.85[0.40-1.96] \\
\end{array}$ & $\begin{array}{l}1.82,1.83 \\
{[0.40-3.02]}\end{array}$ & $\begin{array}{l}0.59,0.72 \\
{[-3.78-} \\
0.95]\end{array}$ \\
\hline
\end{tabular}




\begin{tabular}{|c|c|c|c|c|c|}
\hline & & $\begin{array}{l}\text { swa_b0 }\left[\mathrm{m}^{-1}\right] \\
\text { swa b1 }\left[\mathrm{m}^{-1}\right]\end{array}$ & & & \\
\hline $\begin{array}{l}\text { Simstrat } \\
\text { (ver. 2.1.2) }\end{array}$ & $\begin{array}{l}1 \text { Fraction of wind energy transferred to } \\
\text { seiche energy } \\
2 \text { As above, during summer in lakes }>100 \\
\mathrm{~km}^{2} \\
3 \text { As above, during winter in lakes }>100 \mathrm{~km}^{2} \\
4 \text { Fraction of forcing wind to wind at } 10 \mathrm{~m} \\
5 \text { Fit parameter scaling the shortwave } \\
\text { radiation entering the snow/ice } \\
6 \text { Fit parameter scaling absorption of IR } \\
\text { radiation from sky }\end{array}$ & 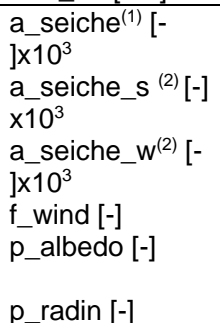 & $\begin{array}{l}8.94,0.75[0.00001-185.8] \\
2.12,1.008[0.099-8.01] \\
2.93,1.17[0.32-12.49] \\
1.05,1.03[0.1-1.97] \\
1.20,1.0[0.49-2.0] \\
0.97,0.97[0.8-1.2]\end{array}$ & $\begin{array}{l}1.35,1.11 \\
{[2.6 \mathrm{e}-4-8.03]}\end{array}$ & $\begin{array}{l}0.95,0.97 \\
{[0.76} \\
0.99]\end{array}$ \\
\hline
\end{tabular}

(1) a_seiche parameter was calibrated for lakes $<100 \mathrm{~km}^{-2}(\mathrm{n}=51)$

(2) a_seiche_s and a_seiche_w parameters were calibrated separately for summer and winter months in lakes $>100$ $\mathrm{km}^{-2}(\mathrm{n}=8)$ 
Table 4. Common output variables reported by local $(\mathrm{L})$ and global $(\mathrm{G})$ models participating in the Lake Sector of ISIMIP2a/b. Highlighted are variables outputted by at least $50 \%$ of lake impact models. Watertemp variable is a full water temperature profile. Naming of lake models and variables are ordered in an alphabetical order (see Table S4 for a list of full variable names).

\begin{tabular}{|c|c|c|c|c|c|c|c|c|c|c|c|c|c|c|c|c|c|c|c|c|c|}
\hline Impact model & $\begin{array}{l}\text { 응 } \\
\text { ఖ } \\
\text { 으 }\end{array}$ & 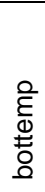 & 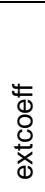 & . & $\begin{array}{l}\stackrel{\varrho}{E} \\
\frac{1}{\Phi} \\
\stackrel{0}{0}\end{array}$ & $\begin{array}{l}\text { 品 } \\
\text { 志 } \\
\underline{0}\end{array}$ & 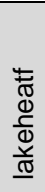 & 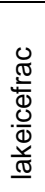 & 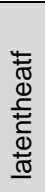 & 윽 & 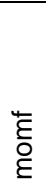 & 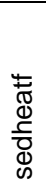 & 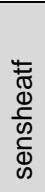 & 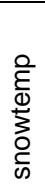 & 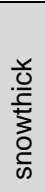 & 茜 & $\frac{\stackrel{\circ}{E}}{\stackrel{\frac{E}{\Phi}}{ \pm}}$ & $\sum_{\infty}$ & 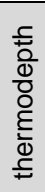 & 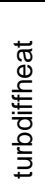 & $\begin{array}{l}\text { 을 } \\
\frac{1}{d} \\
\frac{t}{d} \\
\frac{1}{0} \\
3\end{array}$ \\
\hline Air2water 4par (L) & & & & & & & & & & & & & & & & & $\bullet$ & & $\begin{array}{l}\bullet \\
\text { (1) }\end{array}$ & & \\
\hline Air2water 6par (L) & & & & & & & & & & & & & & & & & $\bullet$ & & $\begin{array}{l}\bullet \\
\text { (1) }\end{array}$ & & \\
\hline $\operatorname{ALBM}(\mathrm{G})$ & & & & & & $\bullet$ & $\bullet$ & & $\bullet$ & $\bullet$ & $\bullet$ & $\bullet$ & $\bullet$ & & $\bullet$ & & & $\bullet$ & & & $\bullet$ \\
\hline ALBM (L) & & & & & & $\bullet$ & $\bullet$ & & $\bullet$ & $\bullet$ & $\bullet$ & $\bullet$ & $\bullet$ & & $\bullet$ & & & $\bullet$ & & & $\bullet$ \\
\hline CLM4.5 (G) & & & & & & & & $\bullet$ & & & & & & & & & & & & & $\bullet$ \\
\hline FLake (L) & & $\bullet$ & & $\bullet$ & $\bullet$ & $\bullet$ & $\bullet$ & & $\bullet$ & $\bullet$ & $\bullet$ & $\bullet$ & $\bullet$ & & & $\bullet$ & $\bullet$ & & $\bullet$ & & $\bullet$ \\
\hline GLM (L) & $\bullet$ & - & & - & & - & & & & & & & & & & - & - & & - & & $\bullet$ \\
\hline GOTM (G) & & & & & & & & & & & & & & & & & & & & & $\bullet$ \\
\hline GOTM (L) & $\bullet$ & $\bullet$ & & & & & & & & & & & & & & $\bullet$ & $\bullet$ & & $\bullet$ & & $\bullet$ \\
\hline LAKE (G) & $\bullet$ & $\bullet$ & $\bullet$ & & & $\bullet$ & $\bullet$ & $\bullet$ & $\bullet$ & $\bullet$ & $\bullet$ & & $\bullet$ & & $\bullet$ & & $\bullet$ & $\bullet$ & $\bullet$ & & $\bullet$ \\
\hline MyLake (L) & $\bullet$ & & & $\bullet$ & & $\bullet$ & $\bullet$ & & $\bullet$ & & & $\bullet$ & $\bullet$ & & $\bullet$ & $\bullet$ & & & $\bullet$ & & $\bullet$ \\
\hline Simstrat (G) & $\bullet$ & $\bullet$ & & & $\bullet$ & $\bullet$ & $\bullet$ & $\bullet$ & - & $\bullet$ & & & $\bullet$ & & $\bullet$ & & $\bullet$ & $\bullet$ & $\bullet$ & & $\bullet$ \\
\hline Simstrat (L) & & - & & $\bullet$ & & $\bullet$ & - & & - & - & & & - & & - & $\bullet$ & - & & - & & - \\
\hline VIC-Lake (G) & $\bullet$ & & & - & $\bullet$ & $\bullet$ & & & - & - & & & - & $\bullet$ & - & - & - & $\bullet$ & - & & $\bullet$ \\
\hline
\end{tabular}

${ }^{(1)}$ the model provides a time-varying estimate of the well-mixed surface layer participating to the heat exchanges with the atmosphere 


\section{Figures}

Figure 1: Map of lakes at local (A) and global (B) scales participating in the ISIMIP2a/b Lake Sector.
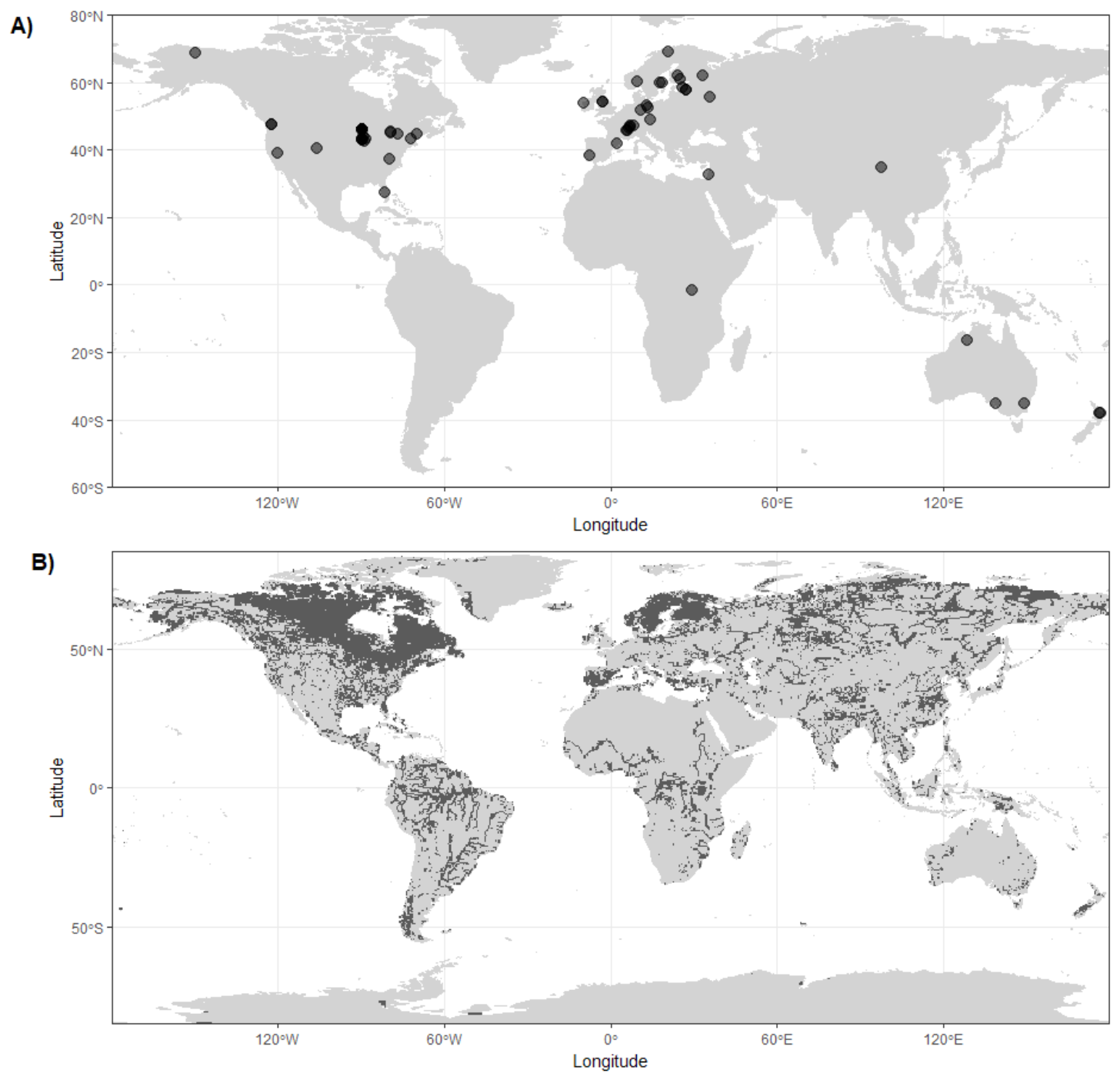
Figure 2: Example output data in the ISIMIP2b Lake Sector. (A) Local model time series of mean annual surface temperature derived from ensemble simulations for a period 1861-2100 (historical and future) averaged across lakes and climate models. Color-coding indicates greenhouse gases scenarios; line types differentiate lake models. (B) Temperature changes by 2070-2099 compared to pre-industrial levels in summer mean temperature at two lake depths simulated with GOTM (local) model evaluated with data from four climate models under RCP8.5. (C) Global outlook for the mean annual surface temperature of lakes by the end of the XXI century (2070-2099) under RCP2.6 simulated with GOTM global.
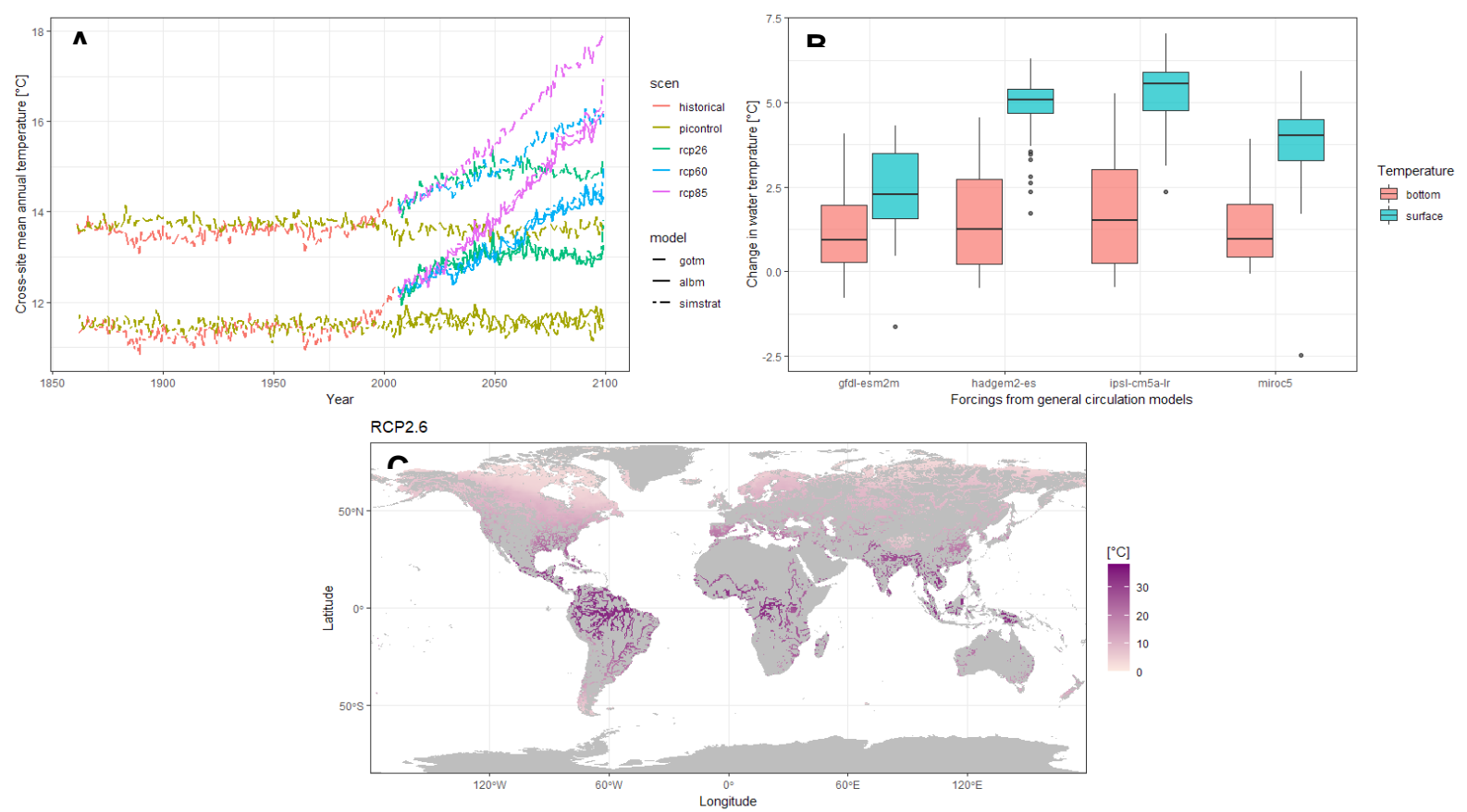
Figure 3. Maps of lake depth, natural lake and reservoir area fractions used in the ISIMIP3 simulation round. Lake depths are derived from GLDB v3 (Choulga et al., 2019), natural lake area fraction from HydroLAKES (Messager et al., 2016) and reservoirs from GRanD (Lehner et al., 2011). Figure adapted from Vanderkelen et al. (2020)
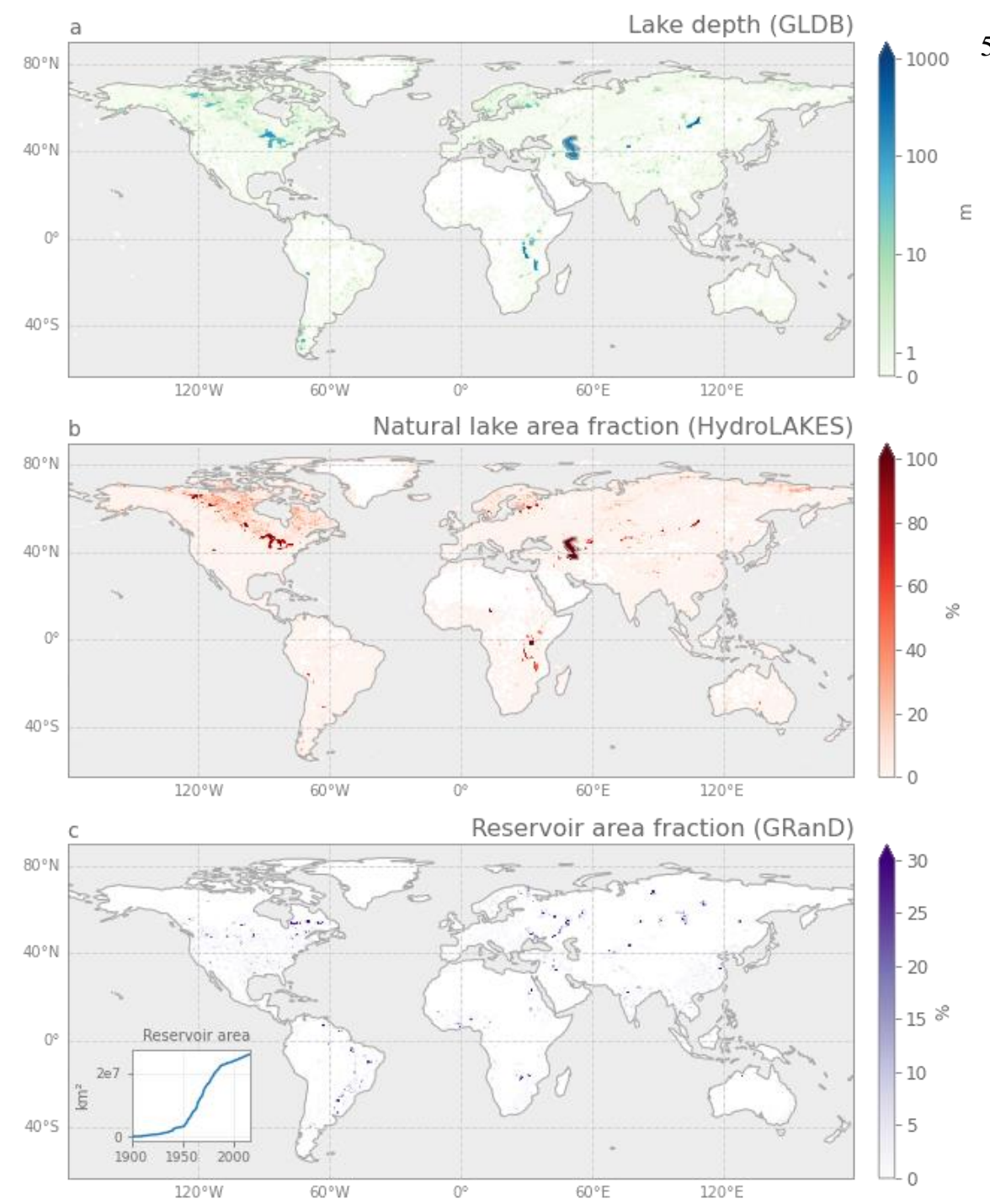